\title{
ACHIEVING NET BENEFITS A ROAD MAP FOR CROSS-SECTORAL POLICY DEVELOPMENT IN RESPONSE TO THE UNINTENDED USE OF MOSQUUTO NETS AS FISHING GEAR
}

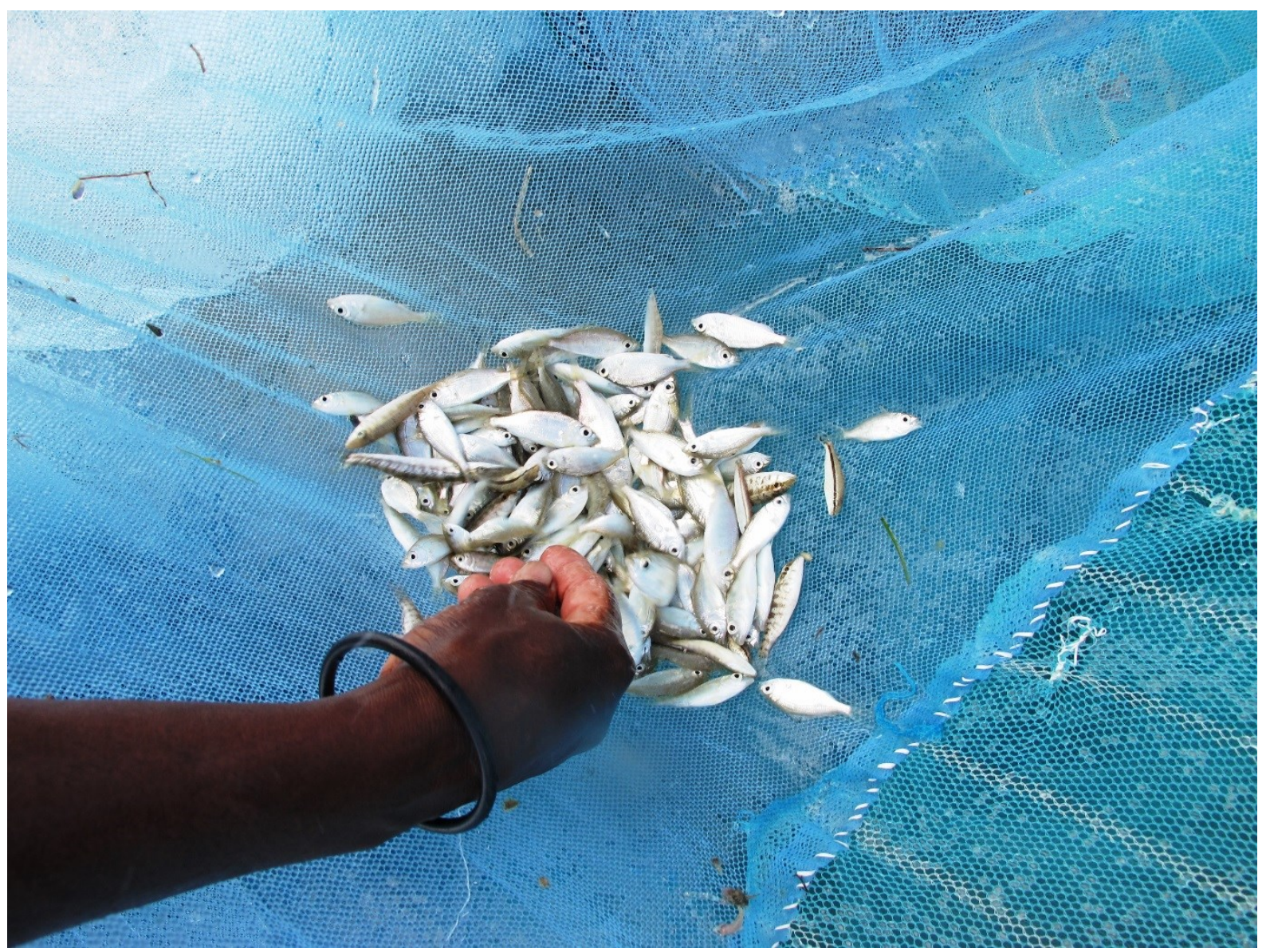

Short. R', ${ }^{1,}$, Addison, P. ${ }^{3}$, Hill, N. ${ }^{4,5}$, Arlidge, W. ${ }^{3}$, Arthur, R. ${ }^{6}$, Berthe, S. , , Castello y Tickell, S. ${ }^{3}$, Coulthard, S. ${ }^{8}$, Lorenz, L. ${ }^{9}$, Sibanda, M. ${ }^{10}$, Milner-Culland, E.J. ${ }^{3}$

\section{IMPERIAL COLLEGE LONDON, DEPARTMENT OF LIFE SCIENCE, SILWOOD PARK, BUCKHURST RD., ASCOT, UK}

EUROPEAN CENTRE FOR ENVIRONMENT AND HUMAN HEALTH, UNIVERSITY OF EXETER MEDICAL SCHOOL, ROYAL CORNWALL HOSPITAL, TRURO, UK INTERDISCIPLINARY CENTRE FOR CONSERVATION SCIENCE, DEPARTMENT OF ZOOLOGY, UNIVERSITY OF OXFORD, UK

ZOOLOGICAL SOCIETY OF LONDON, REGENT'S PARK, LONDON, UK

CENTRE FOR ECOLOGY AND CONSERVATION, UNIVERSITY OF EXETER, PENRYN, CORNWALL, UK

MRAG LTD, 18 OUEEN STREET, LONDON, WIJ SPN, UK

VECTORWORKS, JOHNS HOPKINS BLOOMBERG SCHOOL OF PUBLIC HEALTH CENTRE FOR COMMUNICATION PROGRAMS, BALTIMORE, MD, USA

NORTHUMBRIA UNIVERSITY, DEPARTMENT OF SOCIAL SCIENCES AND LANGUAGES, SANDYFORD RD, NEWCASTLE UPON TYNE, UK

DEPARTMENT OF DISEASE CONTROL, LONDON SCHOOL OF HYGIENE \& TROPICAL MEDIIINE, KEPPEL STREET, LONDON, UK

10. WWF UK, LIVING PLANET CENTRE, RUFFORD HOUSE, BREWERY ROAD, WOKING, UK 


\section{Executive summary}

\section{Aims of the paper}

The use of mosquito nets as fishing gear (equipment) has caused increasing alarm and grown in global prevalence for at least the past ten years across developing nations, with limited individual and no concerted policy responses from the relevant management sectors. The potential negative impacts of the activity are increasingly recognised to span the domains of public health, food and nutrition security, biodiversity conservation and sustainable development (Short et al., 2018).

Whilst the potential for negative impacts of mosquito net fishing (MNF) has received inadequate attention, the benefits the activity represents have been entirely missing from the narrative thus far. Credence must be given to underlying drivers of MNF alongside the existing and growing dependence of fishing individuals and communities on the activity, and critically the yet to be acknowledged potential opportunities MNF represents in light of related socio-economic and environmental change. MNF, which has been portrayed as a last resort of the poor, is increasingly posited to improve livelihoods beyond its subsistence value, promote gender equity due to high female engagement, and potentially access underutilised nutritional resources.

A global-level response to MNF is now overdue, with a need to both develop and implement policies in an interdisciplinary, collaborative nature given the broad impacts. Thus far advances have been hindered by a paucity of detailed understanding of MNF, something which is increasingly being addressed but should be further supported, with the issue largely treated as a hot potato. This paper utilises the outputs of a first cross-sectoral workshop and broad, representative expertise from health, environment and development to road map a way forward for multi-level, cross-sectoral policy development.

There is a need to address MNF as an issue of potentially high risk from both environmental and developmental perspectives, with application of the precautionary principle alongside development of a strategic research agenda to better assess risk-benefit trade-offs. This paper addresses policy needs towards these goals at a range of levels of governance, providing a structure for future research direction and adaptive management, defining organisational and sectoral responsibilities alongside specific policy responses where appropriate. As such, this document aims to inform strategic policy development of multiple levels of governance, but is particularly targeted at high level institutions, such as the WHO and the $\mathrm{FAO}$, who are yet to be effectively engaged in the ongoing conversations surrounding MNF. 


\section{Recommendations in summary}

1. We recommend that the WHO, FAO, UNDP and other UN agencies recognise the need for strategic, collaborative policy development across multiple levels of governance to address the public health, food security and biodiversity conservation threats of the use of mosquito nets as fishing gear.

2. We recommend the development of an adaptive management framework for MNF, starting with an initial cross-sectoral values mapping process at a range of scales, facilitated by the aforementioned agencies and utilising case studies.

3. We acknowledge the continued importance of mosquito net distribution programmes in tackling malaria and recommend that current and future programmes employ a policy of a MNF mitigation hierarchy throughout the relevant stages of distribution.

4. We recommend the identification of Key Affected Areas (KAAs) where parallel policies to the mitigation hierarchy are developed according to local contexts including:

- Use and development of alternative, tailored vector control

- Collaborative efforts towards integrated development programmes specifically tackling drivers of MNF including investment, education and facilitation of social equity and female empowerment.

- Adaptive strategies applied to current fisheries management and specifically a focus on ensuring appropriate use of enforcement measures.

5. We recommend using an integrated, cross-sectoral approach to policy at each step which is critically supported in data collection through information and capacity sharing, and data management/use by a centralised database of open source information. Key to effective delivery of these initiatives will be adoption of a common language across sectors.

6. We recommend drawing on existing goals and advice within sectoral documents, including the Global Technical Strategy for Malaria and Voluntary Guidelines for Securing Sustainable Small-Scale Fisheries, and building these in to a concerted effort to create an enabling policy environment for addressing MNF across sectors.

7. We recommend the engagement of NGOs across public health, development and conservation remits in policy development, particularly facilitation of dialogues at the local level, data sharing and capacity.

8. We recommend the close marrying of private donors and business with high level efforts to create an enabling policy environment, responding as a driving force of diversification and innovation in interventions.

9. We recommend the engagement of academic institutions in furthering our understanding of MNF and enabling evaluation and adaptive responses to policy, alongside a role of fostering and supporting innovations in support of private business.

10. A range of existing, adaptable and novel interventions are proposed from an interdisciplinary brainstorm (Appendix I), though it should be noted this is not intended to be exhaustive. 
Expert contributors to this report:

Dr. Prue Addison

William Arlidge

Dr. Robert Arthur

Sara Berthe

Kitty Brayne

Sofia Castello y Tickell

Dr. Sarah Coulthard Elizabeth Drury O'Neill

Dr. Nick Hill

Dr. Amy Lehman

Peni Lestari

Dr. Lena Lorenz

Dr. Kate McIntyre

Prof. E.J. Milner-Gulland

Dr. Helen Pates Jamet

Dr. Melita Samoilys

Rebecca Short

Mxolisi Sibanda

Prof. Rick Welsh
Interdisciplinary Centre for Conservation Science (ICCS), Uni.

Oxford, UK

ICCS, University of Oxford, UK

MRAG, UK

VectorWorks, Johns Hopkins University, US

Blue Ventures, UK

ICCS, University of Oxford, UK

Northumbria University, UK

Stockholm Resilience Centre, Sweden

Zoological Society of London (ZSL), UK

Lake Tanganyika Floating Heath Clinic, USA

Wildlife Conservation Society, Indonesia

London School of Hygiene and Tropical Medicine, UK

Independent

ICCS, University of Oxford, UK

Vestergaard Frandsen, Switzerland

CORDIO East Africa, Kenya

Imperial College London, UK; ICCS, UK; ZSL, UK

Worldwide Fund For Nature (WWF UK)

Syracuse University, USA 


\section{Introduction}

Mosquito nets continue to be a key part of efforts to tackle malaria worldwide, a disease which is still estimated to kill more than 400,000 people a year and has wide-reaching social and economic impacts in 91 countries (WHO, 2015). These nets, once a somewhat inaccessible commercial product but which are now widely distributed for free or subsidised, are credited with 68\% of an estimated 663 million averted malaria cases since 2000 (Bhatt et al., 2015a). Sub-Saharan Africa continues to bear the heaviest burden of malaria; around 91\% of deaths, and consequently the majority of net distribution efforts are concentrated here (WHO, 2017). The technological development of mosquito nets over recent years has increased their viability as a tool towards eradication of malaria. Beyond the initial provision of physical protection to individuals, Insecticide Treated Nets (ITNs) first aimed to provide a chemical barrier, followed by development of Long Lasting Insecticide treated Nets (LLINS) which removed the need for regular re-treatment and which are considered current best practice (WHO, 2014b). For the purposes of this document we will refer to all of these nets simply as Mosquito Nets (MNs).

Reports of the alternative use of MNs as fishing gear, used to actively target fish in water columns and living on substrates, began to emerge in the early 2000 s (Srivastava, Sarkar \& Patiyal, 2002; Jiddawi \& Öhman, 2002), coinciding with the advent of mass distribution efforts. The practice appears to have increased exponentially ever since and prevalence of MN fishing has recently been posited as far broader and more frequent than previously appreciated at the global level (Short et al., 2018). Although there have been numerous reports of Mosquito Net Fishing (MNF) in the media, little empirical investigation has been conducted, save for a handful of localised case studies; some of which present the issue as negligible in terms of scale and impact on anti-malarial efforts, and others which suggest it is a significant and growing problem particularly in terms of fishery sustainability (McLean et al., 2014; Bush et al., 2016; Eisele, Thwing \& Keating, 2011; Minakawa et al., 2008).

When considering the MNF problem at scale, a number of sometimes competing and frequently anecdotal narratives have emerged in the media and limited literature. First, some authors suggest MNF may be having a negative impact on efforts to reduce malaria. Malaria interventions globally are currently united under a goal of Universal Coverage (UC). UC is defined as universal access to, and use of LLINS by populations at risk of malaria and is an official World Health Organisation (WHO) policy (WHO, 2014a). From the perspective of those tackling malaria using MNs, and in the context of significant investment in mass/continuous distributions towards the goal of UC, any alternative use of nets may be seen as detrimental to these efforts under the assumption that every net used for fishing could otherwise be used on a bed. UC as a goal is intended to offer everyone at risk of malaria the same level of 
protection as a right, but there are also more fundamental implications of reduced bed coverage on malaria incidence as a whole. At a threshold level of coverage within a given community, the impact of those sleeping under LLINs (and these nets must be treated) may confer a degree of protection to the wider population not sleeping under nets through what is termed an epidemiological 'mass effect'. This is where mortality of mosquitoes from interaction with the net insecticides has an abatement impact on their population as a whole, reducing transmission across whole communities (Killeen et al., 2017a). Even a relatively small reduction in coverage may have a significant impact on infection rates. The actual impact of MNF on coverage is unknown, however recent studies have suggested that impacts on total net loss (attrition) of misuse in general, and particularly for fishing, may be minimal at the broad scale (Kilian 2018, unpublished).

Second, some authors suggest capture of juvenile fish, due to small mesh sizes, threatens fishery sustainability and therefore food security. Small scale fisheries, where MNF occurs, contribute around two thirds of global catches for direct human consumption (FAO, 2015) with $90 \%$ of these fisheries are in the world's poorest nations who are reliant on them for their main source of protein and key nutrients (FAO, 2005). So the implications of MNF for nutritional impacts on human health are potentially severe. Current fisheries management centres on ensuring fishing practices are selective in terms of species and sizes (Garcia et al., 2012). This size-based management aims to allow both individuals smaller than of value, and juveniles of target species which have not yet had a chance to breed to escape by ensuring mesh sizes are larger (Sissenwine \& Shepherd, 1987). The mesh size of mosquito nets is necessarily small, at $\sim 1-3 \mathrm{~mm}$, and is capable of indiscriminately catching juveniles of most species. This is also seen to undermine efforts to avoid 'growth overfishing' whereby capture of juveniles and small adults, which are more valuable in terms of yield once they grow larger, means the potential of the fishery is not realised (Diekert, 2012). As such, the predominant view is that fine mesh nets are detrimental to sustainable fisheries and is a key reason this document is required. However, consideration needs to be given to recent counterarguments to these management approaches, of particular relevance to MNF.

There is increasing evidence that current management paradigms side-line the hugely beneficial role that small-bodied fish can play in a sustainable fishery, and that the consequences of this is an additional marginalisation of the most vulnerable, such as MN fishers, whose gears are therefore banned. Balanced harvest theory emphasises the sustainability of harvesting fish according to how productive they may be at varying life stages, promoting capture of highly productive juvenile phases and forage fish. Small-bodied fish constitute a disproportionately valuable resource, particularly when eaten whole, where they provide key micronutrients such as Vitamins A, D and B12, Iron, Zinc and Calcium (Thilsted et al., 2013) crucial for overall health and development, but particularly important for successful malaria recovery (Shankar, 2000), especially in children (Caulfield, Richard \& Black, 2004). Small fish are also easier to dry and can therefore be stored and transported long distances, increasing the catchment of their nutritional benefit (Kolding, van Zwieten \& 
Mosepele, 2015). A balanced harvest scenario inclusive of small-bodied individuals therefore has the potential to produce higher yields concurrent to enhanced nutrition. These small individuals are only accessible with fine mesh nets. It may therefore be speculated that MNF catch is not necessarily damaging to the fishery but may indeed be beneficial in terms of concurrent high yields and nutritional security (Kolding \& Zwieten, 2014).

Third, some authors argue that the ready availability of MNs may encourage new entrants to fisheries and increase overall pressure, which further threatens sustainability. Engaging in MN fishing requires no capital investment, no seafaring knowledge, and no fishing experience meaning that it is open to anyone with a net in proximity to a body of water. Fisheries suffering from high fishing pressure over significant areas may experience 'recruitment overfishing' whereby the numbers of new recruits to the population are not enough to sustain the fishing rate (Sissenwine \& Shepherd, 1987). The expansion of pressure on small-bodied species/life stages may impact the balance of the associated ecosystems. However, such concerns are purely theoretical. Our current understanding of what these impacts might be is poor and likely to be highly context-specific, dependent on the habitats, previous state of the fishery and how MNF is conducted.

The issue of MNF is a complicated one and concerns are not limited to the predominant/direct issues discussed above. Additional environmental concerns surround impacts on associated biodiversity; the use of MNs in shallow water and fragile ecosystems where trampling and physical damage from nets is highly likely (Mangi \& Roberts, 2006). Some concern has been expressed over the impact of net insecticides leaching in to water bodies. LLINs currently employ pyrethroid-class insecticides which, although of low toxicity to mammals, can be highly toxic to other aquatic organisms (Hill, 1989) and are capable of killing small fish on contact. Shallow waters are often host to nursery grounds for species that occupy other habitats during subsequent life stages, so negative impacts on these habitats may have population-level effects. With new fishing gears and techniques often comes conflict, particularly in cases where these gears receive negative attention such as MN fishing has had (Pomeroy et al., 2007). Blame for new and/or damaging fishing gears is often laid with itinerant fishers which may lead to extreme reactions, even violence (Cassels, Curran \& Kramer, 2005). Gender issues may also cause conflict; MNF may be an acceptable and accessible activity for women when its profitability is low, but this can change if and when the activity becomes more profitable, with men then excluding women from a resource they are reliant on (Williams, Williams \& Choo, 2002). Inshore fisheries may indirectly conflict with deeper water and often more commercial fisheries through depletion of nursery grounds and juvenile capture (van der Elst, 2003).

There is currently little evidence of where, to what extent and on whom MNF may have negative impacts. However, theoretically and empirically there is growing evidence of the positive impacts MNF has on individuals and communities. There is a critical need to consider 
who MN fishers are, whether users are opportunists or driven by poverty and other factors. In reality, this is not a 'new' or 'emerging' activity, though evidence shows expansion. Some may have been engaging in the activity for more than a decade, for some it is likely key to bridging seasonal starvation periods (Short et al., 2018; Abbott \& Campbell, 2009) and providing the aforementioned critical micronutrients. For others MNF is likely to be an adaptive response to social and environmental change including desertification and political instability or conflict (McLean et al., 2014). Aside from the potential role as a food and income 'crutch' (Bene, Hersoug \& Allison, 2010), the characteristics of this activity may also mean it has conveyed significant livelihood advantages to communities, with potential over the long term. The ease of use, cultural acceptability and lack of capital investment requirements means opportunities for autonomy for women and the marginalised, which may drive increased equity in fisheries and confer significant developmental advantages (Ranis, Frances \& Alejandro, 2000). Further investigation in to the positive impacts of MNF and the opportunity costs involved in management, particularly on the vulnerable, are imperative.

Underpinning, or perhaps undermining all of these broad concerns is a lack of evidence; basic characterisation of the issue, knowledge of distribution, demographics, socio-economic role or proximate and ultimate drivers and impacts. It is absolutely critical that approaches to MNF, whilst supported by centralised policies, be developed in a context-dependent way, supported by adequate science. There is a critical need for policy makers to maintain objectivity when considering approaches to MNF as whilst the current narrative largely paints negative picture of the activity, there is significant potential for consideration of the opportunities MNF may present for multiple stakeholders. The workshop and outputs presented here were explicitly delivered with these considerations in mind. Whilst this document aims to present a road map towards formation of effective policies to address MNF, the suggestions herein should be considered as under the precautionary principle and will only be useful with a foundation goal of collaborative and efficacious information gathering. 


\subsection{Addressing a cross-cutting issue - a first workshop}

The complex and far reaching potential impacts of MNF straddle issues of food \& livelihoods security, biodiversity conservation, and public health, cutting across many targets within the United Nation's Sustainable Development Goals (SDGs; Table 1). Effective responses to the issue need to bring together the variety of sectoral bodies charged with delivering on these targets. The drivers of MNF are multifactorial; encompassing those of poverty, sustainable and equitable access to resources, and human conflict. Policy and legislatory responses are justifiably required from the multiple sectors concerned with public health, environmental protection, development and natural resource management. This policy brief is the product of a collaborative workshop hosted by researchers from the Interdisciplinary Centre for Conservation Science, Oxford University, at the Oxford Martin School, UK in November 2017. Cross-sectoral representatives from industry, NGOs, science and policy with a broad suite of fisheries, conservation, public health (including specifically malaria focused) and development expertise were invited to participate in a first-of-its-kind discussion about policy development specifically for MNF, from global to local scales.

\subsection{A global public good - but who is responsible?}

MNs are considered a vital public health intervention, so much so that access to their protection can be viewed as a right and therefore MNs as a public good (Guyatt Helen L. et al., 2002). However, where does the responsibility lie when considering mitigation of unintended consequences of their mass distribution, such as fishing? Currently there is no legal responsibility for distribution programmes to ensure correct use of MNs, and clarity on the actual risks to both food security and biodiversity is urgently needed. However, morally an obligation arguably exists for both distributors and end users to ensure that nets distributed for malaria prevention are used for their intended purpose, and disposed of responsibly once finished with.

Some urgency is necessary to resolve these obligations as globally net distribution programmes continue to expand as well as introducing new, 'next generation' nets. These nets are designed to address the increasing resistance of mosquitoes to Pyrethroids and instead employ Chlorfenapyr or Pyriproxifen insecticides for impregnation (Ngufor et al., 2016; N'Guessan et al., 2016). These are more likely to be a risk to humans, with the former considered highly toxic, and there will need to be strong reassurances that risks of potential entry to human food chains, due to nets being used for fishing and drying fish, have been 
TABLE 1 - INTERNATIONAL AGREEMENTS AND ASSOCIATED TARGETS FOR WHICH MOSQUITO NET FISHING IS OF PARTICULAR RELEVANCE.

\begin{tabular}{|c|c|c|c|}
\hline $\begin{array}{l}\text { Convention/ } \\
\text { agreement }\end{array}$ & Goal & Specific target & Mosquito Net Fishing relevance \\
\hline \multirow{2}{*}{ 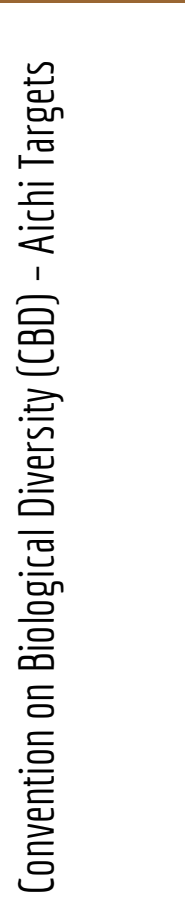 } & Target 6 & $\begin{array}{l}\text { By 2020, all fish and invertebrate stocks } \\
\text { and aquatic plants are managed and } \\
\text { harvested sustainably, legally and applying } \\
\text { ecosystem based approaches, so that } \\
\text { overfishing is avoided, recovery plans and } \\
\text { measures are in place for all depleted } \\
\text { species, fisheries have no significant } \\
\text { adverse impacts on threatened species } \\
\text { and vulnerable ecosystems and the } \\
\text { impacts of fisheries on stocks, species and } \\
\text { ecosystems are within safe ecological } \\
\text { limits. }\end{array}$ & $\begin{array}{l}\text { - } \quad \text { Mosquito Net Fishing (MNF) undermines current fisheries management efforts } \\
\text { - } \\
\text { from the gear and trampling. } \\
\text { - } \quad \text { MNF may be cause damage beyond targeted fisheries resources to other } \\
\text { invertebrate stocks because of its small mesh size. } \\
\text { - } \quad \text { MNF may be encouraging new entrants to fisheries, increasing overall pressure } \\
\text { on resources. }\end{array}$ \\
\hline & Target 10 & $\begin{array}{l}\text { By } 2015, \text { the multiple anthropogenic } \\
\text { pressures on coral reefs, and other } \\
\text { vulnerable ecosystems impacted by climate } \\
\text { change or ocean acidification are } \\
\text { minimized, so as to maintain their integrity } \\
\text { and functioning. }\end{array}$ & $\begin{array}{l}\text { - MNF may cause damage to seagrass beds and coral reef ecosystems through } \\
\text { physical damage and overfishing. }\end{array}$ \\
\hline \multirow{2}{*}{ 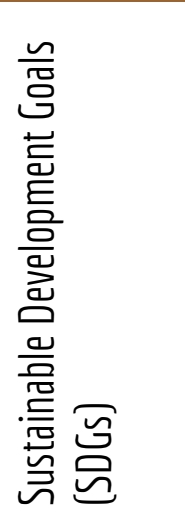 } & \multirow{2}{*}{$\begin{array}{l}\text { Goal } 2 \text { - End } \\
\text { hunger, } \\
\text { achieve food } \\
\text { security and } \\
\text { improved } \\
\text { nutrition and } \\
\text { promote } \\
\text { sustainable } \\
\text { agriculture }\end{array}$} & $\begin{array}{l}2.1 \text { By } 2030 \text {, end hunger and ensure } \\
\text { access by all people, in particular the poor } \\
\text { and people in vulnerable situations, } \\
\text { including infants, to safe, nutritious and } \\
\text { sufficient food all year round. }\end{array}$ & $\begin{array}{l}\text { - MNF may undermine small-scale fisheries (those which utilise coastal or } \\
\text { freshwater resources for subsistence, recreation, or artisanal fishing, typically } \\
\text { with dispersed local ownership) of particular importance to poor and vulnerable } \\
\text { people. } \\
\text { - MNF may provide unique access to fisheries for poor and vulnerable people } \\
\text { who may otherwise be excluded. }\end{array}$ \\
\hline & & $\begin{array}{l}2.2 \text { By } 2030, \text { end all forms of malnutrition, } \\
\text { including achieving, by } 2025 \text {, the } \\
\text { internationally agreed targets on stunting } \\
\text { and wasting in children under } 5 \text { years of } \\
\text { age, and address the nutritional needs of }\end{array}$ & $\begin{array}{l}\text { - MNF may compromise fisheries management efforts in areas where adjacent } \\
\text { - } \quad \text { At least in the short term people may be heavily reliant on MNF for provision of } \\
\text { fish. }\end{array}$ \\
\hline
\end{tabular}




\begin{tabular}{|c|c|c|}
\hline & $\begin{array}{l}\text { adolescent girls, pregnant and lactating } \\
\text { women and older persons. }\end{array}$ & $\begin{array}{l}\text { The provision of small-bodied fish, particularly those eaten whole, are } \\
\text { increasingly appreciated as key for provision of critical micronutrients of } \\
\text { particular relevance to childhood nutrition and development. }\end{array}$ \\
\hline \multirow[t]{2}{*}{$\begin{array}{l}\text { Goal } 3 \text { - } \\
\text { Ensure healthy } \\
\text { lives and } \\
\text { promote well- } \\
\text { being for all at } \\
\text { all ages }\end{array}$} & $\begin{array}{l}\text { 3.3 By 2030, end the epidemics of AIDS, } \\
\text { tuberculosis, malaria and neglected } \\
\text { tropical diseases and combat hepatitis, } \\
\text { water-borne diseases and other } \\
\text { communicable diseases. }\end{array}$ & $\begin{array}{l}\text { - MNF may be reducing bed coverage rates and therefore decreasing efficacy of } \\
\text { anti-malarial efforts. } \\
\text { - } \quad \text { Reduced coverage rates, even at low levels, may reduce the 'mass effect' on } \\
\text { mosquito populations and wider malaria rates. }\end{array}$ \\
\hline & $\begin{array}{l}\text { 3.8 Achieve universal health coverage, } \\
\text { including financial risk protection, access to } \\
\text { quality essential health-care services and } \\
\text { access to safe, effective, quality and } \\
\text { affordable essential medicines and } \\
\text { vaccines for all. }\end{array}$ & $\begin{array}{l}\text { - The commodification of MNs for a purpose other than protection from } \\
\text { mosquitoes may serve to restrict access for the most vulnerable and/or } \\
\text { incentivise alternative uses of MNs. } \\
\text { - MNF May have a bearing on the 'universal coverage' goal for MNs for people in } \\
\text { at risk areas set by the World Health Organisation. }\end{array}$ \\
\hline $\begin{array}{l}\text { Goal } 5 \text { - } \\
\text { Achieve } \\
\text { gender } \\
\text { equality and } \\
\text { empower all } \\
\text { women and } \\
\text { girls }\end{array}$ & $\begin{array}{l}\text { 5.A Undertake reforms to give women } \\
\text { equal rights to economic resources, as well } \\
\text { as access to ownership and control over } \\
\text { land and other forms of property, financial } \\
\text { services, inheritance and natural resources, } \\
\text { in accordance with national laws. }\end{array}$ & $\begin{array}{l}\text { - MNF may remove physical and cultural barriers to women entering fisheries } \\
\text { - MNF may significantly contribute to ability for women to engage in savings } \\
\text { schemes. } \\
\text { - The co-operative approach largely necessary to engage in MNF may encourage } \\
\text { formation of informal co-operatives for women. }\end{array}$ \\
\hline $\begin{array}{l}\text { Goal } 14 \text { - } \\
\text { Conserve and } \\
\text { sustainably } \\
\text { use the } \\
\text { oceans, seas } \\
\text { and marine } \\
\text { resources for } \\
\text { sustainable } \\
\text { development }\end{array}$ & $\begin{array}{l}\text { 14.4 By 2020, effectively regulate } \\
\text { harvesting and end overfishing, illegal, } \\
\text { unreported and unregulated fishing and } \\
\text { destructive fishing practices and } \\
\text { implement science-based management } \\
\text { plans, in order to restore fish stocks in the } \\
\text { shortest time feasible, at least to levels that } \\
\text { can produce maximum sustainable yield as } \\
\text { determined by their biological } \\
\text { characteristics. }\end{array}$ & $\begin{array}{l}\text { - MNF may undermine current fisheries management efforts, though actual } \\
\text { impacts are unknown. } \\
\text { - MNF is broadly illegal, consequently catches and prevalence go unreported and } \\
\text { are not incorporated in to scientific assessments. } \\
\text { - MNF largely occurs in small-scale fisheries where localised co-management (the } \\
\text { sharing of power and responsibility between the government and local resource } \\
\text { users) is often the endorsed mode of management - the socio-economic } \\
\text { complications of MNF make enforcement of bans difficult in these scenarios. }\end{array}$ \\
\hline
\end{tabular}




\begin{tabular}{|c|c|c|c|}
\hline & & $\begin{array}{l}14.7 \text { By } 2030 \text {, increase the economic } \\
\text { benefits to Small Island developing States } \\
\text { and least developed countries from the } \\
\text { sustainable use of marine resources, } \\
\text { including through sustainable } \\
\text { management of fisheries, aquaculture and } \\
\text { tourism. }\end{array}$ & $\begin{array}{l}\text { - } \quad \text { Current evidence of MNF occurs almost exclusively in LDCs (Short et al., 2018). } \\
\text { - } \quad \text { In the short term at least MNF has economic benefits to fishers in LDCs. }\end{array}$ \\
\hline & & $\begin{array}{l}\text { 14.B Provide access for small-scale } \\
\text { artisanal fishers to marine resources and } \\
\text { markets. }\end{array}$ & $\begin{array}{l}\text { - MNF may provide access to previously un-utilised marine resources (juvenile } \\
\text { and small-bodied fish). } \\
\text { - The characteristics of MNF and availability of nets means fisheries resources } \\
\text { may be made accessible to a broader range of user groups. } \\
\text { - The storage and transport potential of small-bodied fish may allow access to } \\
\text { additional, increasingly distant markets for fishers. }\end{array}$ \\
\hline \multirow{4}{*}{ 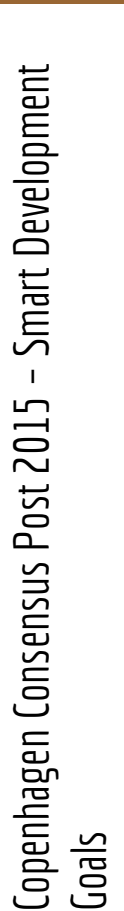 } & \multirow[t]{2}{*}{ People } & Lower chronic child malnutrition by $40 \%$. & $\begin{array}{l}\text { - These recommendations focus on dietary supplements, however, the role of } \\
\text { naturally available sources warrants attention for increased access to nutrients } \\
\text { independent of AID. } \\
\text { - } \quad \text { Fish are increasingly deemed to be of critical importance to global nutrition } \\
\text { development. } \\
\text { - Small-bodied fish provide significant contributions of protein and important } \\
\text { micronutrients and are best targeted with small-mesh gears such as MNs. } \\
\text { - MNF is often conducted by women. Female provisioning in some scenarios can } \\
\text { provide more and better quality nutrition for children than reliance on just male } \\
\text { provisioning (with subsequent positive impacts on overall development). }\end{array}$ \\
\hline & & Halve malaria infection. & $\begin{array}{l}\text { - } \quad \text { MNs are a critical tool in the prevention of malaria } \\
\text { - } \quad \text { The extent of alternative use of MNs is unknown, but MNF may be an important } \\
\text { driver of trade-offs. }\end{array}$ \\
\hline & Planet & Halve coral reef loss. & $\begin{array}{l}\text { - MNF may threaten coral reefs due to physical damage and ecosystem effects of } \\
\text { overfishing. }\end{array}$ \\
\hline & Prosperity & $\begin{array}{l}\text { Improve gender equality in ownership, } \\
\text { business and politics. }\end{array}$ & $\begin{array}{l}\text { - MNF can be a significant leg-up for women in communities where they may } \\
\text { otherwise be excluded from economic development opportunities. }\end{array}$ \\
\hline
\end{tabular}


assessed and addressed. A similarly recent WHO-endorsed promotion of Piperonyl Butoxide, which is combined with Pyrethroids to increase their efficacy, may also increase concerns over harm to wildlife (National Pesticide Information Centre, 2000; Protopopoff et al., 2018). Therefore there is a need to ensure that any shift to new ways of treating nets goes along with strong policies and responsibilities for safe disposal.

The control of harmful fishing practices is justifiably the remit of national fisheries ministries. Currently, national policies towards MNF largely focus on enforcement of gear bans under mesh-size regulations (or sometimes MNF-specific legislation) which may be harmful to particularly vulnerable groups (Short et al., 2018). Enforcement of fisheries laws in the regions of concern is often severely limited by a lack of capacity and funding. In reality much of the enforcement of small-scale fisheries in these regions is facilitated by NGOs, community fishing councils, Beach Management Units (BMUs) and the like through co-management efforts. As an issue of social (and particularly gender) equity, which can fail to be effectively addressed by co-management schemes (Diamond, Squillante \& Hale, 2003), this form of governance would be an unlikely silver bullet, particularly if we assume that MNF is an activity of 'last resort'. Additionally, when dealing with the particularly vulnerable, those enacting these governance systems from within their own communities may be the most conflicted in use of these methods, further compromising the scope of effective enforcement. The common use of gear confiscations and burning (including ceremonial), the scale of which can be large and should not be underestimated (Geoffrey Furber, Ripple Africa, pers. comms), conflicts with the goals and messaging of MN distribution efforts.

The efficacy of ban policies against the use of MNs for fishing has not been assessed at a local scale or otherwise and it is difficult to determine if or where enforcement may be active. The prevalence of the problem at a local level (e.g. Darkey \& Turatsinze, (2014), Short et al., (2018), and Larsen et al., (2018) would certainly suggest that enforcement of MNF bans in many countries by actors external to the community would be prohibitively expensive for already poorly resourced ministries. Vulnerable groups of people fishing close to the shore are more visible and possibly less confrontational. Inappropriate evaluation indicators such as the rate these individuals are arrested may mask the ineffectiveness of MNF bans whilst also having little positive impact on fishery sustainability.

Additionally, the strict differentiation of responsibility between sectors is largely unhelpful, and means that complex, cross-sectoral issues can fall through the cracks. There is a need to engage more across relevant sectors and expertise to adopt policies which address the underlying drivers of illegal extractive activities while also addressing health, poverty reduction and biodiversity conservation goals. MNF is a prime example of why this is important. 


\subsection{Current policies are conflicting or failing}

High-level policies from both the health and environmental management perspectives either give little consideration to the impacts of the prevalence of MNF, or do not holistically tackle its impacts to fishing communities. The predominant response to the rise of mosquito net fishing has been that of fisheries ministries to legislate against the activity, either utilising existing fisheries restrictions on mesh sizes or to introduce novel legislation specifically for this gear e.g. Mozambique where MNF offenses now carry a potential 3-5 year prison sentence. By criminalising the activity you inherently exclude it from management and make it harder to measure and control (Adger, 2006), relying on strong enforcement to make this policy effective. In the case of mosquito net fishing enforcing against inshore, visible fishers (with brightly coloured nets) who, in the case of some marginalised users, may be less likely to question the enforcement or flee can be an easy way of making it look like enforcement is effective; i.e. facilitate a healthy arrest rate.

Significant jail sentences are likely to negatively impact the most vulnerable users and be ineffective deterrents if this is a fishery of last resort. These impacts are of particular concern in the case of female users who may therefore be disproportionately targeted. This policy of enforcement is also in direct conflict with efforts to prevent malaria if potentially useful nets are burned or confiscated, which is unlikely to be politically sustainable. There is a real danger for mosquito nets to become a scapegoat for the wider problems of overexploited fisheries. Whilst this certainly doesn't refute a role of MNF in declining catches, targeting a single unsubstantiated issue would be detrimental to overall management. The potential socio-economic issues arising from this targeted enforcement may be great and anecdotal reports are of MN fishers left in desperate states. The risk of forcing people in to more damaging activities, such as dynamite or cyanide fishing which proliferates in areas of severe desperation should be considered.

Goals of universal coverage (UC) and the methods employed to achieve UC do little to limit the presence of excess nets in distribution areas (Bhatt et al., 2015b) or to address the choices people make as to whether to use a net on their bed or for fishing (Honjo \& Satake, 2014); something we need to understand much better. Aiming for universal coverage may be seen as a pragmatic approach to achieving levels of coverage that drive a 'mass effect' on mosquitoes, whereby mortality rates from insecticide contact may have a populationlevel effect and improve the effective protective range of nets (Howard et al., 2000). However, increasingly effective methods are being developed that optimise delivery modes and numbers thereby making distribution efforts more cost-effective and potentially limit net availability for alternative use (Killeen \& Smith, 2007). Opportunities exist both to understand the dynamics and drivers of MNF and to adapt current policy to avoid negative socio-economic and ecological impacts, and to bridge sectoral gaps to develop synergistic policies that can have broader benefits. 


\subsection{Feedbacks inextricably link sectoral impacts; expert objectives align}

Potentially the strongest illustration of the need for cross-sectoral collaboration in mitigating MNF is the complexity of the potential feedbacks of the activity, rooted as it is within health, economic, cultural and ecological aspects of the communities where it occurs. The food security aspect of MNF has serious ramifications for human health, both positive and negative, particularly the impact of nutritional status on resilience to and recovery from malaria (Shankar, 2000), which need to be addressed. Similarly, a feedback exists between compromised health and an increased likelihood for an individual to engage in illegal fishing activities which are less labour-intensive, such as MNF (Fiorella et al., 2017). Additionally, fishers operating in a compromised ecosystem with few alternative opportunities for food or income and the additional burden of disease are at serious risk of becoming poverty trapped and perpetuating this cycle of issues.

Whilst much discussion has focussed on the negative impacts of MNF, the positive contributions to autonomy for the marginalised, improved food security and livelihoods in the short term pose a question as to how and by whom opportunity costs may be borne. Successful engagement of the development sector in development of interventions to limit the activity will be key, and indeed inform how we might turn control of MNF into opportunities for introduction of sustainable livelihoods for the most vulnerable. In many regions, the conservation of biodiversity and particularly coral reefs is key to maintenance and expansion of tourism incomes, including through opportunities for community-based management (Picard, 2015). Finally, avoiding conflicts between subsistence, small-scale and commercial fishers is key to long term sustainability in fisheries management. If MN fishers continue to be seen to undermine stocks at large then this will be challenging. Whilst this inter-weaving of impacts and their associated feedbacks makes MNF a complicated issue, it also means that, at heart, sectoral motivations with respect to this activity are subject to large overlaps, leading to the conclusion that a highly collaborative, interdisciplinary response will be pivotal to successful management. 


\section{OBJECTIVE SETTING}

The first task of the 2017 workshop was to address the synergistic and antagonistic aspects of feedbacks associated with MNF. The following crosssectoral objectives aimed to guide development of recommendations (Section 2) and engage policy makers across sectors toward common goals:

Healthy people exist in a healthy environment where nobody in waterbased communities dies from malaria, sustainable fisheries are supporting ecosystem function and meeting nutritional needs.

- Improved understanding of the drivers and impacts of MNF, as well as identification of Key Affected Areas (KÄss) is incorporated in to current management objectives across sectors, with its priority increased.

- Policy is geared towards removing the want/need for MNF and moves away from reliance on post-hoc enforcement policies.

Policy-making is evidence-based and data collection is collaborative and inclusive at the local level.

Tailored vector control is accepted as a policy and cost-effective assessment methods developed.

- Implementation of interventions is participatory and collaborative at the local level.

- Gender equity is incorporated in to MNF-focused policy and effectively promoted where MNF issues exist.

Equity and procedural justice is core to delivery of interventions, with these ideals reflected when incorporated in to local institutions and governance.

\section{Interdisciplinary identification of policy avenues}

A two-day workshop was held at the Oxford Martin School on $31^{\text {st }}$ Oct $-1^{\text {st }}$ Nov 2017 . The workshop employed a mixture of expert knowledge elicitation methods. Invited experts were either segregated for intra-sectoral discussions with subsequent contribution to plenary discussions, or randomly mixed in to representative cross-sectoral groups for both brainstorming and refinement activities. Refer to Appendix II for a more detailed methodology. A core aim of the workshop was to consult these experts to elicit key policy arenas in which the MNF issue could and should be addressed. This discussion centred on 
the individual decision-maker, appreciating that the choice to use a MN for malaria prevention or for fishing is affected by both push and pull influences, whereby individuals may be both attracted and forced in to fishing and that both are impacted by current policies.

Four key avenues were identified through workshop discussions (Figure 1) and some examples of specific interventions are given below. Appendix I contains a thorough analysis of key interventions relevant to the policies which were discussed:

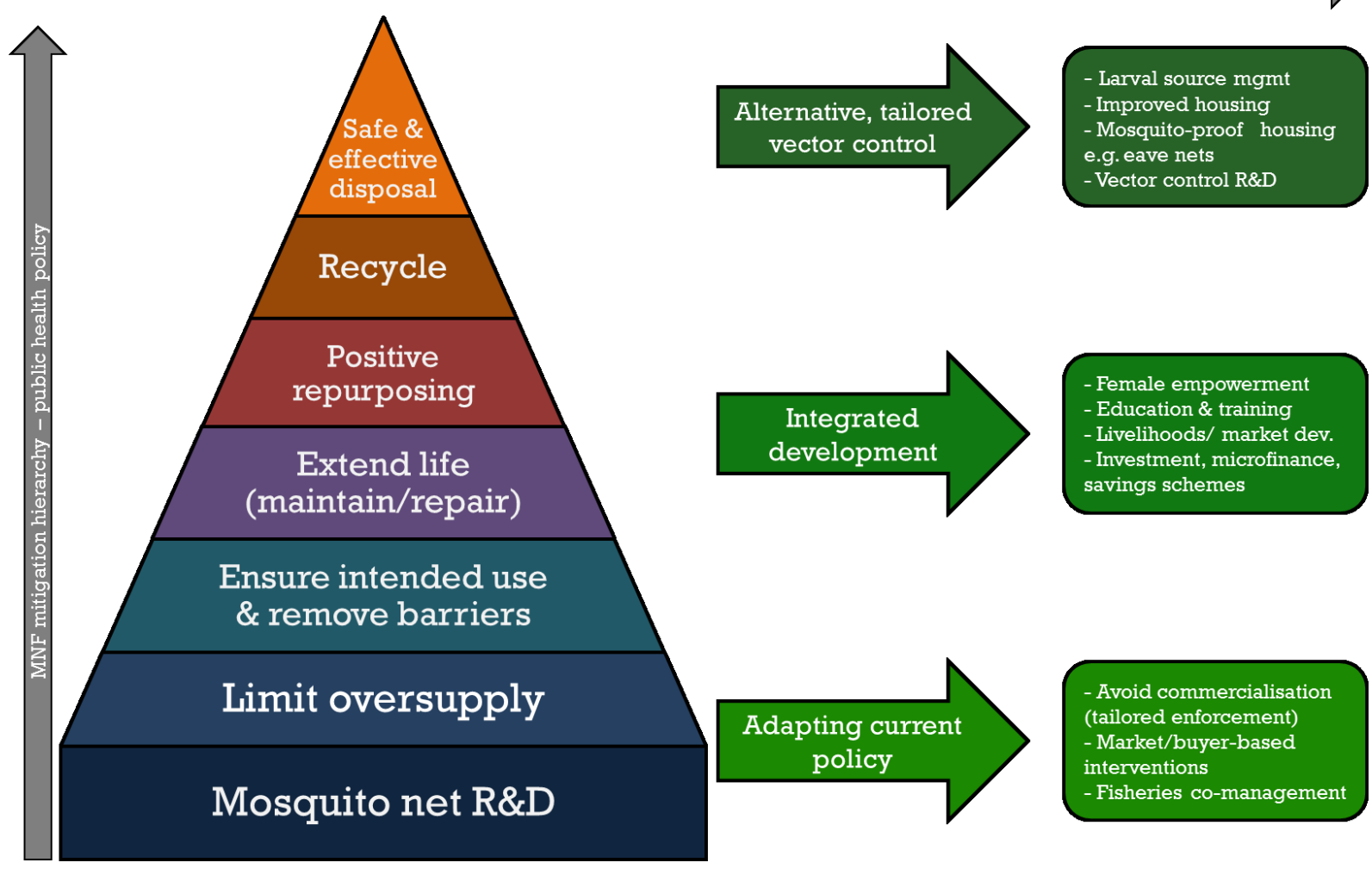

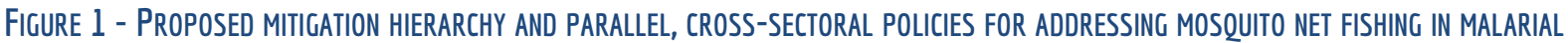
ZONES.

\subsection{Reduce, repurpose, recycle: the mitigation hierarchy}

The ready availability of both new and used nets has been posited as a significant incentive for MNF (Short et al., 2018; Bush et al., 2016). The current WHO policy sets guidelines at a broad population level of 1 net for every 1.8 people to achieve UC. This is designed to necessarily optimise net distribution for practical reasons of resource availability, and unfortunately these targets are still hampered by such limitations, with studies showing that the predominant limiting factor for coverage remains net availability (Koenker, Ricotta \& Olapeju, 2018). However, it has been argued that the level at which these recommendations are set may oversimplify optimisation and lead to over- (and indeed 
under-) supply at local levels (Bhatt et al., 2015b). Moving away from global, blanket guidelines, modelled and empirical studies could aid understanding and optimisation of vector control efforts better at a local scale. Methods already used to understand the mass effect and environmental and social characteristics impacting local epidemiology could be employed at these finer scales to improve efficiency and minimise oversupply (not by reducing nets delivered, but by delivering them to the appropriate households) whilst also optimising the 'mass effect' (Killeen \& Smith, 2007; Hawley et al., 2003; Bhatt et al., 2015b; Dlamini et al., 2017). Further development of such methods could constitute a potential win-win for those addressing MNF and for coverage targets.

The 'public good' argument for access to nets by all is a strong one, however this argument is better posited as a right to protection from malaria vectors, rather than a right to a mosquito net specifically. Other vector control methods can be considered under this argument and yet remain underutilised and underdeveloped (Killeen et al., 2017a), for example, coating the walls and other surfaces of a house with a residual insecticide (Indoor Residual Spraying; IRS) or use of grassroots larval source management methods which reduce potential breeding grounds for mosquitos. For those nets which are distributed, a key objective should be to ensure that practice is geared towards maximising intended use, firstly by removal of physical, social and educational barriers to hanging the nets over beds (inclusive of research and development for new net designs). There is significant evidence of a positive effect on bed coverage of removing barriers to use (Pulford et al., 2011). Highlighting the potential long-term and negative impacts of MNF and promoting sustainable and equitable fisheries use to target communities should also be encouraged. Integrated education, social marketing and behaviour change programmes may be applied to this goal.

Delineating nets as either 'new' (fit-for-purpose), 'end of life' (no longer fit-for-purpose), or 'unserviceable' (in need of disposal) is necessary for management and has important policy implications. The influence of MN condition may be best viewed on a spectrum of policy interventions as part of a 'mitigation hierarchy', where end users may first be actively encouraged to repair nets for continued use on beds (a recommendation already supported by WHO). Once nets are deemed beyond repair for use on beds, they may be repurposed for a number of beneficial vector control uses such as window screening or covering water sources to prevent use for mosquito larvae. These policies will require appropriate and clear communications on care and repair and categories of beneficial repurposing for success. The Alliance for Malaria Prevention has already drafted key repurposing recommendations which should be promptly reviewed and adopted.

Finally, the nets should be safely disposed of. Advice from the WHO on disposal of nets post-use is currently limited to recommendations for safe disposal via incineration (WHO Global Malaria Programme, 2014) - a policy which does not account for shortages of waste 
collection and incineration facilities in many affected countries. Overall, WHO discourages collection of MNs for disposal or recycling unless the potential risks to the universal coverage goal are mitigated, about which there is no clear advice (WHO Global Malaria Programme, 2014). We would argue that this may have perverse impacts in KAAs, beyond the consequent availability of nets for fishing; retaining nets beyond their useful life can impact insecticide resistance in mosquitoes (Norris et al., 2015), and with an urgent need to tackle plastic pollution globally, to have no disposal policy for 1.4 billion plastic nets is negligent. Recycling of MNs is a valid policy option when coupled with development of a collection model that can both relieve strain on waste disposal systems and identify gaps in coverage through needs assessment. Collection models need to consider locally appropriate incentives. Where this recycling is not possible, better policy on safe disposal needs to be developed.

\subsection{Alternative vector control}

The distribution of MNs is currently the largest malaria prevention intervention employed in developing nations, both in terms of investment and operational scale (Bhatt et al., 2015a). However, numerous other interventions exist at various levels of development, deployment and mainstreaming which may be considered underutilised in a policy and funding environment that favours MN distribution. MNs have resonated strongly with the public and generate significant funding, both direct (personal donations) and indirect (national taxpayer contributions to the Global Fund), thanks to the tangible nature of 'give a net, save a life' marketing. Whilst this has advanced the capabilities of international efforts and National Malaria Control Programmes (NMCPs) to deliver nets, it has arguably neglected the deployment and therefore development of alternative methods. Indeed, in developed nations success in malaria control has mainly been achieved through mosquito-proof housing and environmental management (Killeen et al., 2017b). A unilateral reliance on WHO-endorsed products by many countries has stifled innovation in both the development of new MNs and alternative vector control tools due to prohibitively long and bureaucratic approval processes, which can be seen to perversely inhibit the private sector from advancing the fight against malaria. As malaria rates have begun to increase, it is increasingly realised that the reliance on a single tool in the collective toolbox for fighting this complicated disease is ineffective and potentially even harmful to overall efforts.

There is an opportunity, and a renewed appetite, to diversify vector control interventions away from reliance on MNs (Killeen et al., 2017a, 2017b). This diversification could be particularly effective in tackling issues such as MNF, alongside issues of insecticide resistance and intervention fatigue. Whilst a goal of universal coverage of health interventions for at risk populations remains key, the goal of universal coverage of MNs may become less so as other interventions become mainstream. Indoor Residual Spraying (IRS), already broadly deployed in regions of high risk, has been hampered in up-scaling by 
historical issues of DDT use and negative publicity for insecticides more generally (Hlongwana et al., 2013; Sadasivaiah, Tozan \& Breman, 2007). Methods are being developed for more appropriate mosquito-proofing of households in developing settings e.g. eave tubes (Knols et al., 2016). Grass roots innovations in larval source management may alleviate environmental concerns over a focus on larvicide use and legitimise this further as a viable broad-scale intervention. At the level of household/individual protection, insecticide-treated clothing may protect people both inside and outside their homes (Killeen et al., 2017b). For a comprehensive review of current, re-purposed and developing tools in the toolbox refer to Killeen et al., 2017; 'Developing an expanded vector control toolbox for malaria elimination'. A key direction for this diversification may be to focus on cross-sectoral collaborative approaches to improving housing quality for mosquito protection, with all of the associated health, development and security benefits this would also bring.

\subsection{An integrated livelihoods \& development approach}

Global policies on fisheries management increasingly seek to marry food security and ecological objectives towards sustainability under the umbrella of ecosystem-based management (EBM). EBM seeks to incorporate the connections between economic, food security, cultural and wellbeing contributions from fisheries in to management in a more holistic effort which also aims to protect biodiversity as a whole over single stock foci (Bianchi \& Skjoldal, 2008). Renewed efforts through the EBM movement would therefore also seek to diversify management strategies from a singular focus on effort and gearbased methods towards adaptive, stakeholder-driven methods that employ a full toolbox of appropriate spatial, temporal, technological and rights-based tools. In cases such as MNF where poverty drivers are acute, development and livelihood-enhancement options are potentially more effective. Similarly, fisheries and health ministries may do well to adopt policies which complement each other's' objectives on this issue, combine and enhance data gathering to avoid duplication of effort and develop mutually beneficial policies which enable localised tailoring of interventions.

When it comes to drivers, and therefore interventions, MNF is primarily an issue of local livelihoods, vulnerability, food and nutrition security and secondarily one of health and environment. This does not divert the need for policy responses from health and natural resource management bodies, but does pose an opportunity for holistic responses with win-win outcomes across these sectors and others. Addressing the issues which push people into activities that they know are illegal, damaging and ultimately unsustainable requires perspectives that are much broader than simply malaria prevention or fisheries governance. To address the root cause of MNF would require a truly interdisciplinary approach to both future research and interventions, and could potentially reap benefits much broader than reduced malaria prevalence. 
To be effective, alternatives to MNF will need to address opportunity costs for both those highly dependent on its contribution to subsistence, and those who may have enhanced their individual or household wellbeing from increased food and/or incomes. Critically, these alternatives would need to address the potential for a reduction in MNF leading to decreased provision of protein and vital micronutrients, at least in the short term, as well as decreased ability of MNF households to weather seasonal or longer starvation periods. This in itself is representative of the broader need for a culture change in food security policy; an often disproportionate focus on agriculture over wild harvesting, and a disproportionate focus on protein provision over other nutritional value where fisheries are concerned (Thilsted et al., 2014). Both of these are increasingly appreciated as detrimental to the efficacy of policies promoting health and wellbeing of poor households.

MNF represents an example where broad-scale policy-making risks overlooking the importance of both small-scale aquatic food and micronutrient provision. Further research in these areas should be a priority, as should the consideration of modes of access to these resources. Any prohibitive intervention needs to have a good understanding of the tradeoffs involved for both communities and individuals currently engaging in MNF, including long and short term disadvantages in terms of nutritional status. Aside from those directly benefitting in coastal areas, the potential contribution to inland nutrition by these easily dried and transportable fish would need to be much better understood if policymakers wish to avoid negative impacts from interrupting the market chain of what is potentially an important resource. Alternatives would also need to be culturally relevant and sustainable, with appropriate market development and education to maintain this in to the future, building resilience for environmental and societal change. Specific thought needs to be given to displaced peoples, migrants and those living in conflict areas that may be particularly prone to malaria, hunger and MNF. For these people, 'stop-gap' interventions may be necessary in the short term.

\subsubsection{MNF and gender mainstreaming}

Both in terms of integrating development goals into interventions, and also because of the reportedly high representation of female fishers in MNF (Short et al., 2018) and the general lack of attention to, but growing appreciation of, the importance of women in fisheries (Harper et al., 2013, 2017), it would be folly to ignore the benefits of women's empowerment and potential opportunities that MNF brings. One reason MNF is likely to be so appealing to women is due to a culture of inequity in access to and distribution of fisheries resources, which rarely provide for an entire household when harvested by men. Women all over the world have therefore developed complicated economic strategies with which to fill these gaps (Porter et al., 2008). These inequities may restrict women to exploiting marginal aquatic areas, such as ditches, rice fields and shallow marine habitats 
such as seagrass beds (de la Torre-Castro et al., 2017); areas where small fish proliferate and fine mesh nets are an advantage. MNF is one of very few opportunities open to women in many communities to a) directly engage in a primary fishing activity which is broadly culturally accepted, b) directly provide a source of high quality nutrition and/or trade-off for staple food sources independent of men and c) gain an independent source of income which can be invested in wellbeing enhancements that have broad personal and societal benefits, such as education, housing improvements and entrepreneurship.

Investment in women can have a disproportionately positive community-wide impact and women can be more disposed to investment in the future and more likely to engage in savings schemes (Ranis, Frances \& Alejandro, 2000; Porter \& Mbezi, 2010). MNF may promote autonomy for women through independent access to food and income which could be considered a small step towards more equitable access and use of fisheries resources for women were this activity to be capitalised upon. These benefits should not be negated in the pursuit of effective interventions - a particularly pertinent point when considering the efficacy of bans. Secondly, the self-organisation, development of markets and general promotion of financial literacy that may be associated with activities such as MNF present an opportunity for development interventions. Where women engaging in purely agricultural activities may spend the majority of their days alone on their family plot, fishing is a sociable and necessarily co-operative activity which not only contributes to women's wellbeing, but also social and economic mobility. Investing in other strategies for maintaining these benefits, by capitalising sustainably on MNF's contributions to gender equality and creating further opportunities for women, would probably have a huge impact on reducing the prevalence of MNF.

\subsection{Adaptive management applied to current policy}

Whilst we have made arguments against the sole use of current enforcement policy for MNF, we also appreciate the role it must play in addressing cases of MNF where the drivers of the activity may be less directly connected to poverty. Whilst current evidence points to MNF remaining a subsistence or artisanal activity, larger-scale activities and threats of commercialisation have also been identified, such as use of the catch from MNF in animal feed production. External actors and market drivers may have a significant impact on the scale at which MNF is conducted. Where these drivers are significant, monitoring and enforcement is likely to be necessary.

In these scenarios, which are likely to be complicated and still ultimately linked to poverty, adaptive fisheries co-management initiatives as part of EBM, recognising the role of communities and individuals and including them in development of contextually appropriate legislation and delivery of enforcement. Co-management is grounded in community participation, aiming for fully inclusive and representative development of 
management plans with local people. Government ministries and NGOs play a supporting role and deliver the scientific bases for these plans, with an interdisciplinary team critical to successful guidance (Berkes, 2009).. It would also be prudent for malarial interventions and co-management initiatives to aim to complement one another and include goals of human wellbeing development, involving relevant expertise in this area when necessary, and combining education and behaviour change efforts to align messaging and increase impact. Additionally, market-based drivers and external influences should be addressed with appropriate mechanisms that target organisations/buyers throughout the market chain.

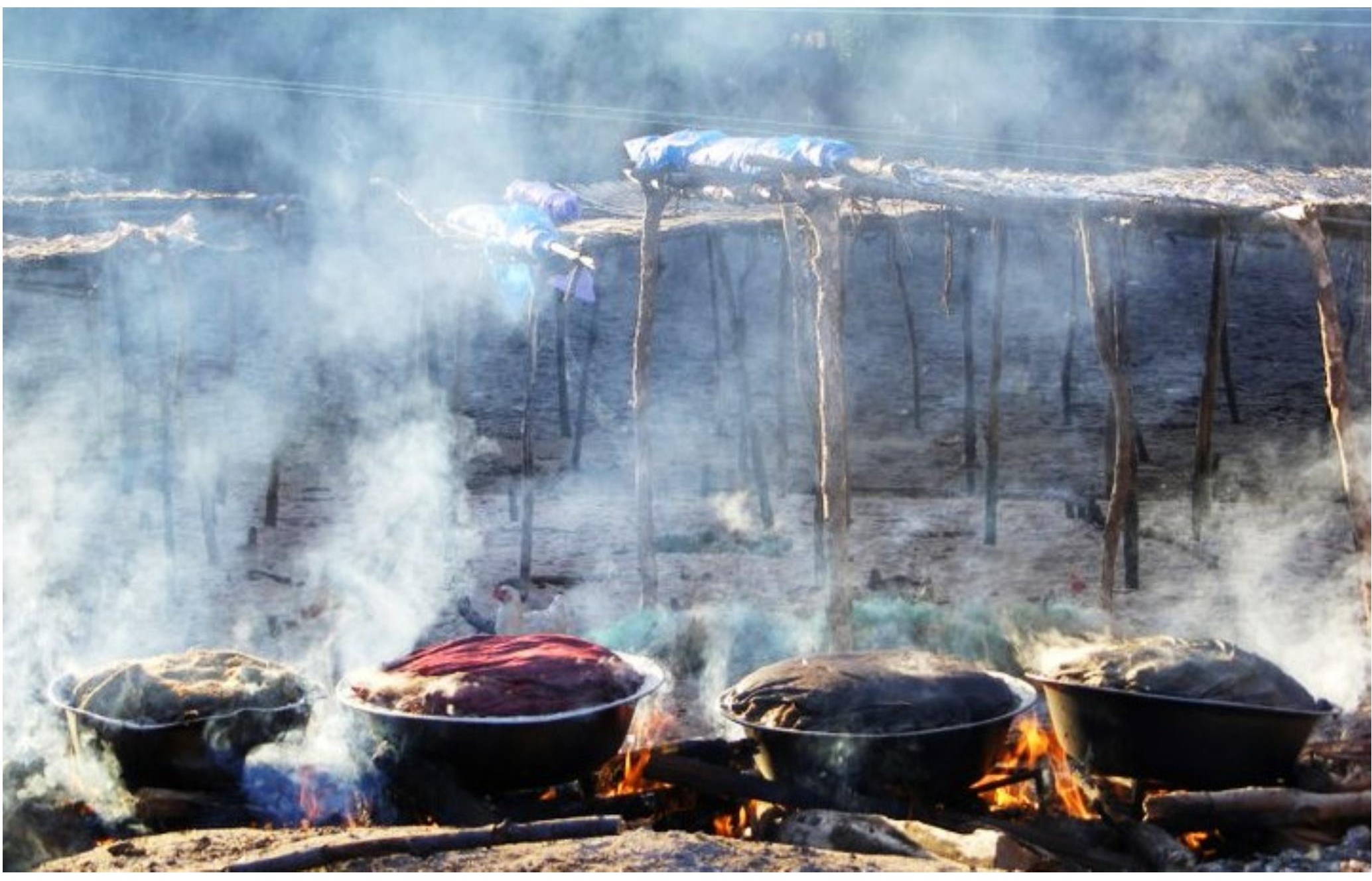




\section{Sectoral recommendations: translation to governance and action}

\subsection{International policy makers (WHO \& FAO)}

From the arguments presented here it is clear that there are significant benefits to be reaped from encouraging a cross-sectoral approach to policy development for MNF, and this will ideally start from the top levels, including the United Nations. There is a need to support collaborative actions, particularly engagement of the Food and Agriculture Organisation as perhaps the most meaningful organisation in terms of fisheries management, whilst appreciating the central role that the World Health Organisation must continue to play. Specifically for MNF, the WHO and FAO should collaboratively support identification of key affected areas for MNF, both areas of current activity but also areas of risk due the dynamic nature of the issue and potential impacts of social and environmental change. Policy should then support the role of adaptive management in addressing MNF in these areas, determining common ground, and importantly a common language, between sectors for development of a broad-scale adaptive management framework alongside promotion of context-dependent, win-win solutions.

Framework development should begin with the facilitation of a one-off, cross-sectoral values-mapping process at a variety of scales. The goal of this process would be to explicitly recognise areas of agreement and difference between stakeholder sectors on the issue of MNF, building on the information within this report. Conducting this exercise at a range of levels from first local (utilising case studies) to international will ensure rigour in the outputs, which can then be used directly to inform an adaptive management framework for a particular intervention area that accounts for issues at all levels. The establishment of a centralised database of localised information, to which all sectors may contribute, would be a pivotal tool in the delivery and communication of successes/failures in adaptive strategies and should be a priority for international policy development. The additional benefits of such a database to the devolved targets of the various sectors, both in terms of practical data provision and in terms of building a collaborative culture would be great.

A key role for international policymakers in tackling MNF will be to spearhead a culture change in policy development that enables innovation in vector control. Moving away from reliance on MNs, both in key affected areas for MNF but also for other problem areas, will require efforts to change the investment landscape and provide incentives for increased engagement of researchers, business and the private sector, both operationally for research and development but with the additional benefit of diversifying funding. Importantly, but bearing in mind the need to promote and design these adaptive management strategies in parallel, there is a need for the WHO to provide a vastly more 
comprehensive set of MN disposal and repurposing policies, inclusive of better environmental and human health safety standards and appreciation of national waste disposal limitations. These recommendations align well with the strategic visions of both the WHO Global Technical Strategy for Malaria (GTSM) and the Roll Back Malaria Action and Investment to Defeat Malaria (AIM) reports (World Health Organization, World Health Organization \& Global Malaria Programme, 2015; Global Partnership to Roll Back Malaria, 2015) which lay out the necessary policy developments needed in 2016-2030 to achieve current targets. Both reports commit to increased engagement across sectors in order to 'strengthen the enabling environment', policies which support an integrated development approach within which MNF should be a key consideration. The goal of ensuring enabling policy environments is mirrored in the FAO's Voluntary guidelines for securing sustainable small-scale fisheries in the context of food security and poverty eradication, which highlights the need to better embed the sector in a wider institutional and policy context (FAO, 2015).

All three documents also contain recommendations for the advancement of gender equality and give some credence to the critical interplay between food security and health, and specifically malaria. However, the recommendations from WHO and RBM focus solely on agriculture and do not account for the huge nutritional importance of fisheries and subsequent impact on overall health and wellbeing, and therefore the role of MNF, a gap we feel needs to be urgently addressed. Accordingly, the FAO will play a key role in endorsing adaptive policies towards fisheries management specifically for MNF, recognising the unique feedbacks involved in MNF to avoid negative impacts of inappropriate top-down and/or blanket enforcement policies. This will require a parallel culture change and difficult conversations over challenges to the impacts of MNF, particularly where they are erroneously seen to be ubiquitous. Innovation and a more rapidly adaptive policy environment are central to the policies outlined, and information regarding MNF should be incorporated into research and development plans. We believe that better data collection and sharing across organisations, and use of that data for evidence-based interventions and participatory action is particularly important, accounting for the difficult decisions being made by those in severe poverty.

\subsection{National implementing bodies}

At the national level it will be critical for government ministries responsible for fisheries management (and law enforcement), education, public health and development to begin to align policies on MNF and develop action plans which account for localised characteristics of MNF. This will require better co-operation on information gathering and incorporation of MNF-specific data needs into micro-planning (needs assessment) processes for MN distribution and other malaria interventions, such as those recommended by the Alliance 


\section{CROSS-SECTORAL STEERING GROUPS:}

The facilitation of a values-mapping process would provide an opportunity for the development of cross-sectoral steering groups to operate at international, and national levels. Key affected areas would be specifically addressed by regional groups (where the issue is cross-border) to provide guidance for national and local level implementation of the adaptive management framework. A key role would be to identify and engage expertise to guide delivery for interdisciplinary aspects of interventions, ensuring modes of communication between disparate groups who may not have an obvious obligation to do so under the current modes of management.

Additionally, the steering groups can act as a proactive policy feedback mechanism for evaluation of the framework, direction of research and development funding as issues arise, and a conduit for information of value to public engagement efforts. At the uppermost level this group should comprise of representatives from key United Nations programmes (WHO, FAO, UNDP, UNEP), The Alliance for Malaria Prevention (AMP), international conservation and development NGOs and key academic groups with relevant expertise in natural resource management and population health evaluations.

At regional and national levels it will be important to include significant operational expertise from delivery of conservation and fisheries

management (e.g. co-management), MN distribution and evaluation programmes and existing integrated development programmes to formulate context-appropriate advice for implementation. Generating funding for both an urgent values-mapping process, and the facilitation of the cross-sectoral steering groups must be a first priority.

for Malaria Prevention (Erskine \& Rockwood, 2013). Fisheries and development bodies should be involved in MN distribution planning processes from the start to identify and assuage potential problem areas, and this should also extend to subsequent surveillance, monitoring and evaluation efforts. Importantly, local, district, provincial and national (or the equivalent) authorities need to ensure they are communicating across hierarchies to mitigate geographical inequalities in opportunity costs and the potential for conflict. This will additionally ensure traceability and accountability for MN distribution programmes, identifying issues such as net leakage and corruption in the early stages of a programme. 
Consequent policy and action plan development should aim to remain collaborative. For example, behaviour change programmes can integrate messages across delivery modes such as schools, health clinics and fishing councils. Operationally, many sectors employ similar methods for deployment and evaluation of interventions, use similar modes of access and communication, and many of the messages delivered align with overarching sustainable development goals - opportunities to combine or enhance these operations to achieve multiple sectoral objectives should be sought. An additional benefit of this will be to limit duplication of effort and greatly improve the quality of information gathered. The development of multi-sectoral action groups, which are advocated for within the AIM report and have shown great success, critically need to engage with the fisheries sector wherever appropriate. National bodies should also aim to support the identification of KAAs and in the short-term feed back information on the scale and variability of MNF to both international bodies and also academic researchers seeking to better understand the characteristics and drivers of this activity.

\subsection{Non-Governmental Organisations}

Engagement from NGOs is required for an effective response to MNF at local and national levels, with broad support for policies set at the international level. Public health, development and conservation-focused organisations all have a critical capacity to act as a unifying gateway to local information, governance and influence. NGOs should be engaged particularly for facilitation of dialogues at the local level, including for neutral engagement of MN fishers themselves, needs evaluations and values-led discussions of community-led interventions. For those NGOs focussed on conservation and/or fisheries management, particularly those supporting co-management initiatives, incorporation of MNF into management and critical challenges to enforcement-centric policies when engaging with local governance would be of benefit. The diversification of vector control will critically need to be supported by malaria-focussed NGOs with appropriate donor support and alignment of goals. Accordingly, the targeting of public support and prominence of public campaigns must be adapted to new strategies. NGOs can play a crucial role in guiding evidence-based interventions, including informing academic research, and should be sought and consulted on issues of surveillance, monitoring and data collection.

\subsection{Private donors and business}

Donors and private business can both respond to and influence policy direction. However, this is something that has been expressed as lacking in terms of malaria interventions, particularly vector control, resulting in a paucity of investment in innovation to address emerging challenges. Donors can both direct and respond to the actions of private business, depending on the challenge they seek to meet. Under a freer investment 
landscape with our recommended international policy changes, responsible developments from the private sector would be at the centre of improving adaptive capacity to meet challenges such as MNF and reduce the dependence on MNs as an intervention, including through innovative funding channels that marry this sector with national implementing bodies, NGOs and research bodies. Opportunities exist for engagement and promotion of responses from a wide variety of companies, from pharmaceuticals, to tech, to communications.

Endorsement of products and strategies by the WHO will remain critical to funders. However, the promotion of a rapidly responsive policy environment would address temporal barriers and improved communications as well as the open integration of interdisciplinarity and engagement of external expertise into future developments. This may serve to cut out some of the prohibitive barriers. For example engaging with human development NGOs may serve to highlight a number of operational barriers to delivery and success of an intervention during development stages, allowing adaptive capacity to be worked into product design. Similarly, funders should seek to release funds for field trials of new products under varying contexts independently of direct R\&D funds. Platforms and seed funding opportunities which facilitate mixing of sectors, interdisciplinary conversations and opportunities for collaboration that engage with private business and showcase needs to donors (e.g. hackathons, competitively commissioned design solutions) should be encouraged both externally (governments/UN etc.) and within private companies.

\subsection{Academic research \& funders}

Academic research has the potential to support much of the decision-making involved in employing adaptive management policies, as well as playing a pivotal role in innovation, research and development of new vector control products. Funding and research effort should be directed towards research which seeks both to set baselines for understanding the role of MNF in socio-ecological systems in order to inform development of appropriate interventions, and to improve the collection and use of data for monitoring and evaluation of subsequent interventions employed. Priorities include understanding gender aspects of MNF (the role played and benefits accrued by women in particular), the nutritional impact of MNF across vulnerable groups and assessing MNF impacts on fisheries and benthic habitats. The promotion of interdisciplinary science and robust methods to answer these questions should be at the core of funding objectives, alongside active involvement of incountry researchers and research institutions.

Academic research has been highlighted by the GTSM as central to fostering and sharing innovations and solutions to global malaria challenges. This is particularly true for the creation of new tools and vector control strategies which may enable adaptive 
management policies to be employed in key MNF affected areas, with wider benefits.

Academic and private sector collaborations should be fostered to advance these efforts and provide guidance to one another on specific development needs for both operational and economic viability of new solutions.

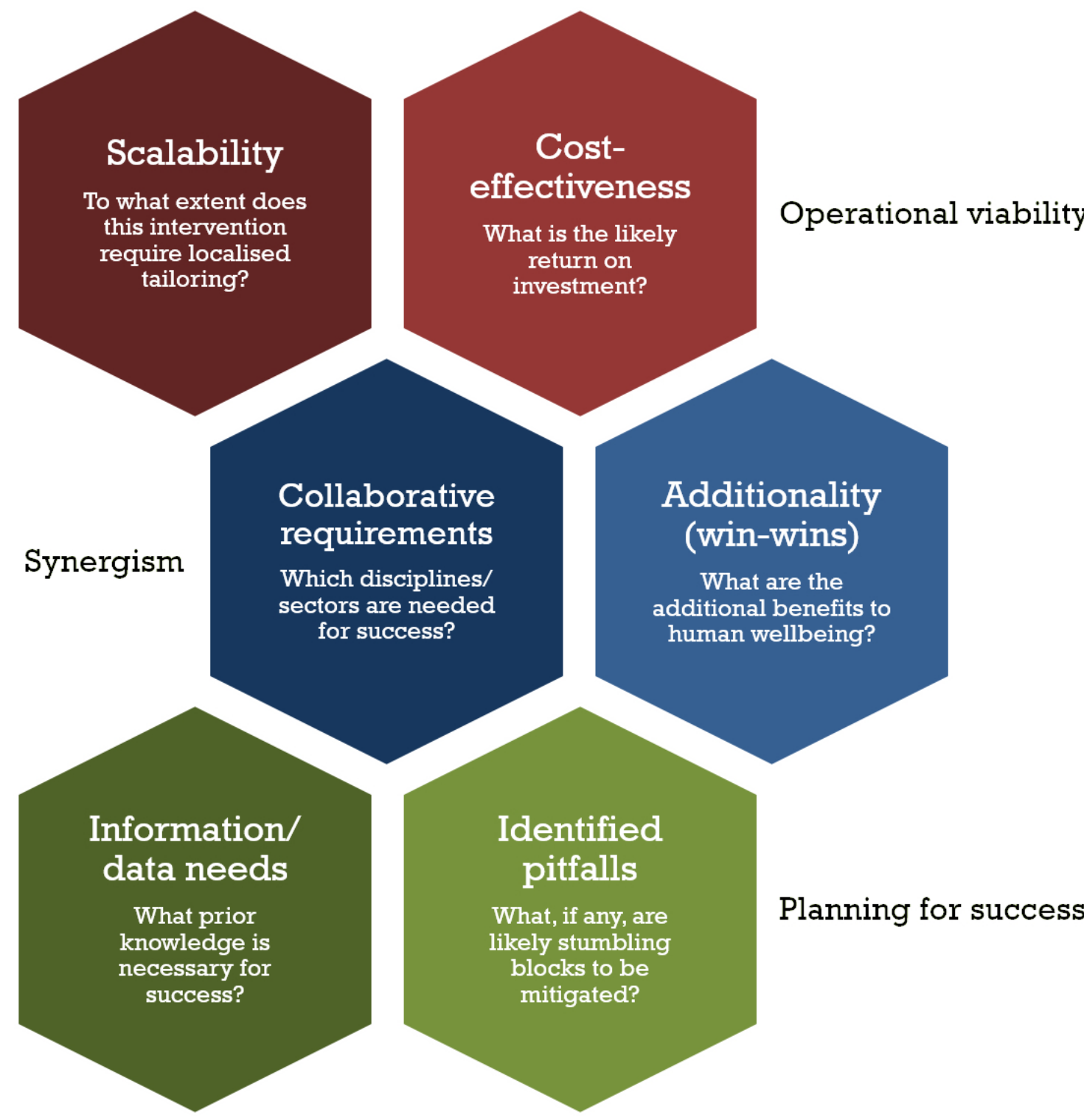

FIGURE 2 - BASIC ASSESSMENT FRAMEWORK FOR MOSQUITO NET FISHING INTERVENTIONS. 


\section{Developing implementation}

In the development of adaptive strategies to MNF, and vector control generally, a critical appraisal of current and future interventions as part of a 'toolbox' is key at a range of scales, including for MN distribution itself. This should aim to identify potential contextual issues and key stumbling blocks, providing advice as to applicability, cost-effectiveness, current state of development (and therefore needs) and complementarity with other interventions. Interdisciplinary expertise should be sought for all assessments. In Appendix I an assessment of interventions for responses to MNF challenges is provided from a brainstorm undertaken at the interdisciplinary workshop in November 2017, drawing on cross-sectoral expertise using the assessment framework (Figure 2).

Whilst 'Evidence of success/failure' is clearly a necessary aspect of these assessments, we include this as a given under aspects of 'Planning for success' and would advocate for a more structured approach to gathering this evidence based on our previous recommendation for the support of a centralised database, rather than encouraging adhoc assessments by implementation teams. This is in no way intended to be an exhaustive list, neither are interventions to be considered in isolation. Some address MNF very specifically, whilst others seek to address underlying drivers of MNF. However, we hope that this example of a framework may act as clear evidence of the need and potential additionality from an interdisciplinary approach, an illustration of the feasibility of adaptive management, and a catalyst for a rapid change to the policy culture surrounding malaria vector control and MNF. 
APPENDIX I - INTERDISCIPLINARY ASSESSMENT OF INTERVENTIONS IN RESPONSE TO MOSQUITO NET FISHING CHALLENGES IN KAAS. * N.B. NUMEROUS ALTERNATIVE VECTOR CONTROL SOLUTIONS EXIST OR ARE IN DEVELOPMENT BUT WERE NOT ASSESSED BY THE GROUP OWING TO A DEARTH OF VIABLE KNOWLEDGE. CONTINUED DEVELOPMENT AND INNOVATION WAS HOWEVER A KEY OUTPUT OF THE INTERVENTIONS DISCUSSION.

\begin{tabular}{|c|c|c|c|c|c|c|}
\hline Intervention & Scalability & Cost-effectiveness & Collaborative requirements & Additionality & Information/data needs & Identified pitfalls \\
\hline $\begin{array}{l}\text { Mosquito-proof } \\
\text { housing solutions } \\
\text { e.g. eave tubes, } \\
\text { screening, wall } \\
\text { linings }\end{array}$ & $\begin{array}{l}\text { Appropriate for most } \\
\text { permanent/semi- } \\
\text { permanent dwelling } \\
\text { types. }\end{array}$ & $\begin{array}{l}\text { More expensive than } \\
\text { MNs but can be more } \\
\text { durable. } \\
\text { Protection for } \\
\text { household over } \\
\text { individuals. }\end{array}$ & $\begin{array}{l}\text { Could operate } \\
\text { through current } \\
\text { health intervention } \\
\text { bodies. } \\
\text { Architectural and } \\
\text { design engineers. }\end{array}$ & $\begin{array}{l}\text { Minor housing } \\
\text { improvements. } \\
\text { Marginalised groups } \\
\text { more likely to be } \\
\text { covered. }\end{array}$ & $\begin{array}{l}\text { General dwelling } \\
\text { designs } \\
\text { \& family structures. } \\
\text { Culturally appropriate } \\
\text { aesthetics }\end{array}$ & $\begin{array}{l}\text { Uptake hampered by } \\
\text { aesthetics. } \\
\text { Outdoor sleepers not } \\
\text { covered. }\end{array}$ \\
\hline $\begin{array}{l}\text { Housing } \\
\text { improvements }\end{array}$ & $\begin{array}{l}\text { Need to adapt to } \\
\text { dwelling types. } \\
\text { Simplest dwellings } \\
\text { may not be suitable or } \\
\text { need additional work. }\end{array}$ & $\begin{array}{l}\text { Highly context } \\
\text { dependent. } \\
\text { Dwellings needn't be } \\
\text { fully proofed for } \\
\text { effective protection. } \\
\text { Very long-lasting. }\end{array}$ & $\begin{array}{l}\text { Development sector. } \\
\text { Private housing } \\
\text { industries. }\end{array}$ & $\begin{array}{l}\text { Benefits to general } \\
\text { health, standard of } \\
\text { living, social mobility. } \\
\text { Knock-on benefits - } \\
\text { able to invest in other } \\
\text { improvements. }\end{array}$ & $\begin{array}{l}\text { General dwelling } \\
\text { designs } \\
\text { \& family structures } \\
\text { Culturally appropriate } \\
\text { aesthetics. } \\
\text { Local capabilities. }\end{array}$ & $\begin{array}{l}\text { Requires continued } \\
\text { investment in } \\
\text { maintenance. } \\
\text { May exclude poorest } \\
\text { households. }\end{array}$ \\
\hline $\begin{array}{l}\text { Increased indoor } \\
\text { residual spraying } \\
\text { (IRS) }\end{array}$ & $\begin{array}{l}\text { Already prevalent - } \\
\text { infrastructures exist in } \\
\text { many places. } \\
\text { Requires re-treatment } \\
\sim 2 \text { years and specialist } \\
\text { treatment. }\end{array}$ & $\begin{array}{l}\text { Can be less cost- } \\
\text { effective than MN } \\
\text { distribution. Re- } \\
\text { application every } 6 \\
\text { months. } \\
\text { Protection for } \\
\text { household over } \\
\text { individuals. }\end{array}$ & $\begin{array}{l}\text { Relatively specialist. } \\
\text { Could be combined } \\
\text { with other door-to- } \\
\text { door activities. } \\
\text { Environmental } \\
\text { management. }\end{array}$ & $\begin{array}{l}\text { Jobs for locals a win- } \\
\text { win. }\end{array}$ & Local acceptability & $\begin{array}{l}\text { Contributions to } \\
\text { insecticide resistance. } \\
\text { Safe use of DDT. } \\
\text { Aesthetics and smell } \\
\text { not appealing. } \\
\text { Invasive. }\end{array}$ \\
\hline $\begin{array}{c}\text { Increased use of } \\
\text { spatial repellents e.g. } \\
\text { coils, vapourisers }\end{array}$ & $\begin{array}{l}\text { Successful use in lots } \\
\text { of various settings. } \\
\text { Lots of different } \\
\text { products available - } \\
\text { can adapt to } \\
\text { environment. } \\
\text { Continuous supply } \\
\text { system needed. }\end{array}$ & $\begin{array}{l}\text { Re-supply possibly } \\
\text { costly. } \\
\text { Could be made } \\
\text { cheaper with } \\
\text { increased use (bulk). }\end{array}$ & $\begin{array}{l}\text { Social marketing \& } \\
\text { education. } \\
\text { Modes of distribution. }\end{array}$ & $\begin{array}{l}\text { Can use outdoors } \\
\text { (currently area of } \\
\text { increasing risk). } \\
\text { Covers groups and } \\
\text { individuals. }\end{array}$ & $\begin{array}{l}\text { Local acceptability. } \\
\text { Research in to efficacy } \\
\text { in different } \\
\text { environments. } \\
\text { Health impacts (largely } \\
\text { unknown) }\end{array}$ & $\begin{array}{l}\text { Efficacy of different } \\
\text { products variable - } \\
\text { needs more } \\
\text { research/recommend } \\
\text { ations list? } \\
\text { Acceptability and use } \\
\text { is variable. }\end{array}$ \\
\hline $\begin{array}{l}\text { Increased use of } \\
\text { Larval Source } \\
\text { Management e.g. }\end{array}$ & $\begin{array}{l}\text { Already being scaled } \\
\text { up, but localised } \\
\text { tailoring needed. }\end{array}$ & $\begin{array}{l}\text { Various different } \\
\text { scales - from large } \\
\text { operations on lakes to }\end{array}$ & $\begin{array}{l}\text { Specialists required. } \\
\text { Community-LSM can } \\
\text { be combined with }\end{array}$ & N/A & $\begin{array}{l}\text { Potential larval } \\
\text { sources. }\end{array}$ & $\begin{array}{l}\text { Some methods may } \\
\text { be damaging to } \\
\text { environment and }\end{array}$ \\
\hline
\end{tabular}




\begin{tabular}{|c|c|c|c|c|c|c|}
\hline $\begin{array}{l}\text { community standing } \\
\text { water management, } \\
\text { larviciding }\end{array}$ & & $\begin{array}{l}\text { promotion of } \\
\text { community LSM e.g. } \\
\text { well covering }\end{array}$ & $\begin{array}{l}\text { other education \& } \\
\text { behaviour change } \\
\text { messaging }\end{array}$ & & $\begin{array}{l}\text { Identification of } \\
\text { hotspots. }\end{array}$ & $\begin{array}{l}\text { impact insecticide } \\
\text { resistance - larviciding } \\
\text { water bodies, } \\
\text { introduced species, or } \\
\text { large scale habitat } \\
\text { alteration. }\end{array}$ \\
\hline $\begin{array}{l}\text { Use of less } \\
\text { durable/cotton nets } \\
\text { (tear when used for } \\
\text { fishing?) }\end{array}$ & $\begin{array}{l}\text { Easy to switch to } \\
\text { different nets but } \\
\text { would need separate } \\
\text { distribution }\end{array}$ & $\begin{array}{l}\text { More need for re- } \\
\text { distribution more } \\
\text { frequently (less } \\
\text { durable), significant } \\
\text { disadvantage over } \\
\text { more durable nets }\end{array}$ & $\begin{array}{l}\text { Significant policy } \\
\text { change }\end{array}$ & N/A & $\begin{array}{l}\text { Identification of high } \\
\text { MNF-risk areas. } \\
\text { MNF net alteration } \\
\text { methods - will this } \\
\text { have desired effect? }\end{array}$ & $\begin{array}{l}\text { Creation of market to } \\
\text { fishing communities } \\
\text { for more durable nets } \\
\text { distributed elsewhere } \\
\text { - premium on tough } \\
\text { nets. }\end{array}$ \\
\hline $\begin{array}{l}\text { Community-based } \\
\text { fisheries co- } \\
\text { management (e.g. } \\
\text { Locally Managed } \\
\text { Marine Areas w/MNF } \\
\text { exclusion) }\end{array}$ & $\begin{array}{l}\text { Can be complicated } \\
\text { initially but often } \\
\text { models of co- } \\
\text { management are } \\
\text { replicable to a great } \\
\text { degree. }\end{array}$ & $\begin{array}{l}\text { Opportunity costs for } \\
\text { some in the short } \\
\text { term. } \\
\text { Implementation costs } \\
\text { can be high. } \\
\text { Better, more } \\
\text { sustainable incomes } \\
\text { in long term. }\end{array}$ & $\begin{array}{l}\text { Fisheries ministries, } \\
\text { local NGOs (scientific } \\
\text { guidance), } \\
\text { development NGOs } \\
\text { (e.g. gender } \\
\text { mainstreaming), } \\
\text { strong buy in from } \\
\text { local leaders } \\
\text { (relationship building) } \\
\text { and fishers. } \\
\text { Education \& } \\
\text { behaviour change. }\end{array}$ & $\begin{array}{l}\text { Sustainable use of } \\
\text { resources promoted } \\
\text { throughout fishery = } \\
\text { long term food } \\
\text { security. } \\
\text { Community } \\
\text { empowerment. } \\
\text { Promotion of equity in } \\
\text { resource use and } \\
\text { inclusion of women } \\
\text { aids development. } \\
\text { Biodiversity } \\
\text { protection. }\end{array}$ & $\begin{array}{l}\text { Understanding of } \\
\text { drivers of MNF locally } \\
\text { (avoid harm). } \\
\text { Detailed } \\
\text { characterisation of } \\
\text { fishery and market } \\
\text { chain needed. } \\
\text { State of relevant } \\
\text { ecosystems/fish } \\
\text { stocks. }\end{array}$ & $\begin{array}{l}\text { Reliance on } \\
\text { enforcement of MNF } \\
\text { bans could hurt most } \\
\text { vulnerable w/out } \\
\text { appropriate } \\
\text { alternatives. } \\
\text { Migrant fishers can be } \\
\text { excluded from } \\
\text { management. }\end{array}$ \\
\hline $\begin{array}{l}\text { Alternative income } \\
\text { generation (non- } \\
\text { fishery e.g. alt. } \\
\text { livelihoods } \\
\text { (aquaculture), } \\
\text { microcredits, Village } \\
\text { Savings and Loans } \\
\text { Associations) }\end{array}$ & $\begin{array}{l}\text { Needs to be locally } \\
\text { specific (w/prior } \\
\text { research) but } \\
\text { generalised models } \\
\text { can be followed. }\end{array}$ & $\begin{array}{l}\text { Very costly set-up but } \\
\text { with potentially very } \\
\text { high returns. }\end{array}$ & $\begin{array}{l}\text { Would work best if } \\
\text { fully collaborative at } \\
\text { range of scales with } \\
\text { fisheries mgmt., } \\
\text { development, } \\
\text { conservation \& health. } \\
\text { Should be combined } \\
\text { with community- } \\
\text { based fisheries mgmt. }\end{array}$ & $\begin{array}{l}\text { Huge additional } \\
\text { benefits across } \\
\text { communities - likely to } \\
\text { be response to } \\
\text { multiple issues inc. } \\
\text { MNF. } \\
\text { Can have impacts } \\
\text { across all aspects of } \\
\text { sustainable } \\
\text { development. }\end{array}$ & $\begin{array}{l}\text { In-depth } \\
\text { characterisation of } \\
\text { current livelihoods, } \\
\text { local resources, } \\
\text { opportunities viable } \\
\text { for expansion, cultural } \\
\text { influences, } \\
\text { available/growing } \\
\text { markets. }\end{array}$ & $\begin{array}{l}\text { Sustained input and } \\
\text { effective } \\
\text { monitoring/evaluation } \\
\text { necessary. } \\
\text { Need to ensure MNF- } \\
\text { specific niche is filled. } \\
\text { Must address food } \\
\text { and nutrition security. } \\
\text { Focus on MNF can } \\
\text { look like rewarding } \\
\text { illegal activity. }\end{array}$ \\
\hline
\end{tabular}




\begin{tabular}{|c|c|c|c|c|c|c|}
\hline $\begin{array}{c}\text { Women's } \\
\text { empowerment \& } \\
\text { gender } \\
\text { mainstreaming } \\
\text { (fishery and/or non- } \\
\text { fishery) }\end{array}$ & $\begin{array}{l}\text { Will require localised- } \\
\text { tailoring, though some } \\
\text { lessons are } \\
\text { transferable. }\end{array}$ & $\begin{array}{l}\text { Potentially costly but } \\
\text { with very high returns. }\end{array}$ & $\begin{array}{l}\text { Huge benefits could } \\
\text { be reaped from } \\
\text { increasing gender- } \\
\text { research and inclusion } \\
\text { across all sectors and } \\
\text { operations, with a } \\
\text { specific objective to } \\
\text { understand and } \\
\text { address role of MNF. }\end{array}$ & $\begin{array}{l}\text { Shown to have large } \\
\text { impact on overall } \\
\text { development efforts, } \\
\text { sustainable resource } \\
\text { use, and human } \\
\text { wellbeing. }\end{array}$ & $\begin{array}{l}\text { Detailed planning to } \\
\text { navigate cultural } \\
\text { difficulties. } \\
\text { Characterisation of } \\
\text { current livelihoods. } \\
\text { Identification of } \\
\text { opportunities. }\end{array}$ & $\begin{array}{l}\text { Culturally difficult in } \\
\text { some regions. } \\
\text { Requires sustained } \\
\text { input. }\end{array}$ \\
\hline $\begin{array}{c}\text { Reduce net } \\
\text { oversupply and } \\
\text { improve distribution } \\
\text { efficiency e.g. spot } \\
\text { checks, household } \\
\text { data verification }\end{array}$ & $\begin{array}{l}\text { Could be scaled to all } \\
\text { NMCPs or target KAAs. }\end{array}$ & $\begin{array}{l}\text { Several aspects could } \\
\text { be costly and require } \\
\text { significant manpower } \\
\text { on top of distribution } \\
\text { costs. }\end{array}$ & $\begin{array}{l}\text { Collaborations with } \\
\text { other on-the-ground } \\
\text { organisations, } \\
\text { particularly for data } \\
\text { provision and } \\
\text { evaluation, could } \\
\text { significantly cut costs. }\end{array}$ & $\begin{array}{l}\text { Waste reduction - } \\
\text { impact on marine } \\
\text { debris and landfill. } \\
\text { Information collected } \\
\text { would be useful for } \\
\text { numerous other } \\
\text { initiatives. }\end{array}$ & $\begin{array}{l}\text { Detailed supply-chain } \\
\text { information (not } \\
\text { always available) } \\
\text { Detailed census data } \\
\text { alongside } \\
\text { characterisation of } \\
\text { localised living } \\
\text { conditions. }\end{array}$ & $\begin{array}{l}\text { Corruption may } \\
\text { persist. }\end{array}$ \\
\hline $\begin{array}{l}\text { Promote positive net } \\
\text { re-purposing for } \\
\text { worn nets e.g. } \\
\text { covering water } \\
\text { bodies, use in } \\
\text { agriculture }\end{array}$ & $\begin{array}{l}\text { Could be scaled to all } \\
\text { NMCPs. }\end{array}$ & $\begin{array}{l}\text { Very cost-effective - } \\
\text { additional value in } \\
\text { MNs }\end{array}$ & $\begin{array}{l}\text { Other sectors can } \\
\text { reinforce messaging } \\
\text { and advise on non- } \\
\text { vector control uses } \\
\text { that are safe/useful } \\
\text { e.g. in agriculture. } \\
\text { Education \& } \\
\text { behaviour change. }\end{array}$ & $\begin{array}{l}\text { Waste reduction. } \\
\text { Additional vector } \\
\text { control e.g. larval } \\
\text { source management } \\
\text { by covering wells etc. } \\
\text { Positive uses in food } \\
\text { production, } \\
\text { construction etc. (very } \\
\text { useful resource) }\end{array}$ & $\begin{array}{l}\text { Research in to local } \\
\text { repurposing - what is } \\
\text { potentially harmful? }\end{array}$ & $\begin{array}{l}\text { Messaging may be } \\
\text { confusing, sectoral } \\
\text { priorities may have an } \\
\text { influence. } \\
\text { Impact on insecticide } \\
\text { resistance will likely } \\
\text { remain unknown. }\end{array}$ \\
\hline $\begin{array}{l}\text { Develop disposal } \\
\text { mechanisms for 'end } \\
\text { of life' nets }\end{array}$ & $\begin{array}{l}\text { Very challenging in } \\
\text { rural areas, and even } \\
\text { some urban settings } \\
\text { which lack existing } \\
\text { waste- } \\
\text { collection/disposal } \\
\text { mechanisms. }\end{array}$ & $\begin{array}{l}\text { Very expensive in } \\
\text { areas with no current } \\
\text { system. Even if just } \\
\text { focused on MNs } \\
\text { would require } \\
\text { logistical costs. }\end{array}$ & $\begin{array}{l}\text { Could operationally } \\
\text { combine with a) MN } \\
\text { distribution (e.g. } \\
\text { exchange programme) } \\
\text { or b) concerted effort } \\
\text { to improve overall } \\
\text { waste management by } \\
\text { governments. }\end{array}$ & $\begin{array}{l}\text { Could bring significant } \\
\text { improvements to local } \\
\text { sanitation, air quality } \\
\text { (reduce open air } \\
\text { burns) and reduce } \\
\text { ecological damage } \\
\text { (marine litter, ghost } \\
\text { fishing). } \\
\text { Opportunity for } \\
\text { energy generation }\end{array}$ & $\begin{array}{l}\text { Tracking of distributed } \\
\text { nets would need to be } \\
\text { accurate for exchange } \\
\text { programmes, net } \\
\text { leakage at all scales } \\
\text { could reduce } \\
\text { coverage long term. } \\
\text { Definition and mode } \\
\text { of I.D. of 'end of life' } \\
\text { nets. }\end{array}$ & $\begin{array}{l}\text { Current WHO policy } \\
\text { for safe final disposal } \\
\text { is incineration - } \\
\text { facilities may not exist. }\end{array}$ \\
\hline
\end{tabular}




\begin{tabular}{|c|c|c|c|c|c|c|}
\hline & & & & $\begin{array}{l}\text { with incinerator } \\
\text { investment. }\end{array}$ & & \\
\hline $\begin{array}{l}\text { Develop recycling } \\
\text { mechanisms for ‘end } \\
\text { of life' nets }\end{array}$ & $\begin{array}{l}\text { Expensive to facilitate } \\
\text { through state. } \\
\text { Community-collection } \\
\text { model (e.g. Net-Works; } \\
\text { net-works.com) could } \\
\text { present scaling-up } \\
\text { option. }\end{array}$ & $\begin{array}{l}\text { Dependent on value } \\
\text { of recycled products. } \\
\text { Costly start-up. }\end{array}$ & $\begin{array}{l}\text { Private sector } \\
\text { involvement for } \\
\text { research, marketing } \\
\text { and investment. } \\
\text { Circular economy } \\
\text { advocates. } \\
\text { NGOs (conservation } \\
\text { or development) }\end{array}$ & $\begin{array}{l}\text { Waste reduction. } \\
\text { Community collection } \\
\text { model brings } \\
\text { additional incomes } \\
\text { and microfinancing } \\
\text { opportunities to } \\
\text { communities. }\end{array}$ & $\begin{array}{l}\text { Potential processes, } \\
\text { products and markets. } \\
\text { Receptiveness to } \\
\text { community collection. } \\
\text { Definition and mode } \\
\text { of I.D. of 'end of life' } \\
\text { nets. }\end{array}$ & $\begin{array}{l}\text { Health-related issues } \\
\text { from residual } \\
\text { insecticides on } \\
\text { products. } \\
\text { In theory MNs should } \\
\text { be a temporary } \\
\text { resource (in } \\
\text { elimination of malaria) } \\
\text { - impact on } \\
\text { investment? } \\
\text { Commodification of } \\
\text { MNs? }\end{array}$ \\
\hline $\begin{array}{c}\text { Alter net design- } \\
\text { less fit-for-fishing } \\
\text { and/or more fit-for- } \\
\text { purpose e.g. } \\
\text { biodegradable } \\
\text { materials }\end{array}$ & $\begin{array}{l}\text { Would depend on } \\
\text { ultimate cost of } \\
\text { product. } \\
\text { Ideally would be } \\
\text { tailored (physical } \\
\text { design) to different } \\
\text { scenarios so scaling } \\
\text { not main priority }\end{array}$ & $\begin{array}{l}\text { Unknown - costs } \\
\text { would need to be kept } \\
\text { low to be competitive. }\end{array}$ & $\begin{array}{l}\text { Private sector \& WHO } \\
\text { (rapid assessments } \\
\text { and } \\
\text { recommendation). } \\
\text { Can incorporate } \\
\text { needs in to existing } \\
\text { research. } \\
\text { Combine with } \\
\text { recycling/disposal } \\
\text { research. }\end{array}$ & $\begin{array}{l}\text { Enhancements to } \\
\text { vector control efficacy. } \\
\text { Increased social } \\
\text { acceptability of MNs } \\
\text { (e.g. more } \\
\text { comfortable) }\end{array}$ & $\begin{array}{l}\text { Nuanced } \\
\text { understanding of } \\
\text { flaws in current MN } \\
\text { designs. } \\
\text { Comprehensive } \\
\text { review of deployment } \\
\text { methods for fishing. }\end{array}$ & $\begin{array}{l}\text { Potential for } \\
\text { inappropriate MNs to } \\
\text { be distributed to } \\
\text { some communities. }\end{array}$ \\
\hline
\end{tabular}




\section{Background}

The primary aim of the workshop was to enable an open and solutions-focused discussion regarding the issue of the use of mosquito nets as fishing gear. The event brought together a mixture of operational and research staff with positions closely associated with marine conservation, fisheries management, public health and human development, to represent a broad range of perspectives and expertise. As a poorly understood issue, the workshop focused on a two stage discussion around: a) defining the problem and what we know and don't know; b) determining appropriate avenues for policy development going forward, and reviewing existing or novel interventions that may contribute to these recommendations.

The structure of the workshop allowed free flowing conversation, open opinions and new ideas, whilst drawing on aspects of structured decision making (SDM) to facilitate constructive and practical outputs which explicitly recognise conflicts, uncertainties and variable priorities. To achieve this, the workshop operated under the Chatham House Rule, whereby attendees were free to use the information discussed in the workshop, but the source of any information or views could not be identified.

\subsubsection{Selection of participants}

Participants were invited based on several years of networking and discussions, which largely relied on snowball sampling and the results of an extensive literature review, conducted by the first author. Prior to formal recruitment a breakdown of necessary expertise and organisational representation was drafted to ensure best possible balance. Financial barriers to participation from, for example, NGO representatives were removed thanks to kind support from the Oxford Martin School, Imperial College London and the Zoological Society of London.

Participants were provided with a brief background document prior to the workshop in accessible language which aimed to provide basic context and enable a minimum knowledge-level for all participants across relevant sectors. A recommended reading list of key literature was also provided. Prompts were provided throughout the workshop alongside guiding questions, as designed by the author, to ensure activities were performed and questions were addressed according the pre-planned structure but building in flexibility given the nature of the subject. For breakout sessions, each group were designated a facilitator who was provided with detailed instructions. All plenary sessions were formally facilitated by Dr. Prue Addison.

\section{Defining policy needs; identification of drivers and impacts}

Attendees were split into sectoral groupings as per their expertise: Conservation (C), fisheries and development (F\&D), health (malaria, H). Groups then independently brainstormed the questions below, with a prompt to think about extent, geographic spread, timescale, severity and their confidence in their assessments. Groups then reconvened in plenary in order to discuss and categorise the outputs. 
What positive and/or negative consequences do your sectoral group feel may be attributed to MNF?

What do you perceive are the likely drivers of the decision for a person to use a mosquito net for fishing? NB - this decision context implies that anyone owning a net knows what its intended purpose is and the consequences of not using it on their bed; this may not always be the case so please allow for this in your thinking.

\section{Cross-sectoral objective setting}

Attendees were once more split into sectoral groups in order to brainstorm some potential objectives for MNF, in order to guide future research and decision-making (ultimately policy development). Whilst the groups sought an ultimate 'end' objective, they were also encouraged to focus on key 'means' objectives which would facilitate the achievement of that end, and whether objectives were long or short term. Groups could be selfish as to their own sector's goals here, and facilitators worked the groups towards the end objective if appropriate.

What do you, as a group, ultimately want with respect to MNF? What would an ultimate goal/change for the future look like?

The workshop attendees re-convened in plenary to discuss each group's objectives and honed down a final set of key objectives, removing any overlaps/redundancy

\section{$\underline{\text { Identification of synergies and conflicts }}$}

Attendees were randomly mixed so that all sectors were represented in each of four groups. The objectives set previously were then re-discussed in light of the mixed perspectives:

Can we have all of these objectives?

Participants were asked to group objectives which may work well together/complement one another, and identify any hindrances or conflicts between objectives for further discussion.

\section{Operationalisation and feasibility}

In this creative session, groups were once again randomly mixed with representatives of each sector in each group, and asked to come up with as many existing, adaptable and/or novel potential interventions for management of MNF. Groups were also encouraged to think about which existing policy avenues each intervention might be relevant to.

What specific interventions exist (or are thought of now) which may be implemented or adapted to achieve the set objectives? What are the policy mechanisms by which they could be employed? 


\section{Contact: reshort86@gmail.com}

\section{Citation:}

Short. R, Addison, P., Hill, N., Arlidge, W., Arthur, R., Berthe, S., Castello y Tickell, S., Coulthard, S., Lorenz, L., Sibanda, M., Milner-Gulland, E.J. (2019) Achieving net benefits: A road map for cross-sectoral policy development in response to the unintended use of mosquito nets as fishing gear.

\section{Contributors:}

Brayne, K., Drury O'Neill, E., Lehman, A., Lestari, P., Mclntyre, K., Pates Jamet, H., Rowcliffe, M., Samoilys, M., Welsh, R.

All images @ Rebecca Short

This road map was produced as part of Dr. Rebecca Short's doctoral thesis 'Disentangling the net: The socio-ecological dynamics of mosquito net fishing' funded by the NERC Doctoral Training Programme, Science and Solutions for a Changing Planet, Grantham Institute, Imperial college London.

Additional funds were contributed by:

The Zoological Society of London Conservation and Policy Department, through the Our Sea Our Life project.

The Daisy Balogh Fund, Institute of Zoology, Zoological Society of London.

In-kind contributions towards workshop hosting from the Oxford Martin School.
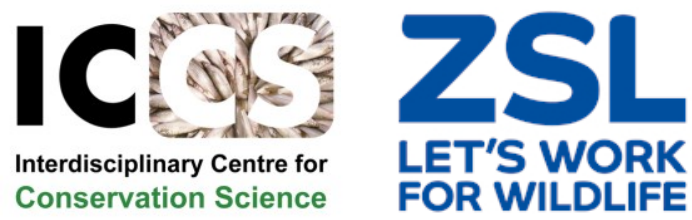
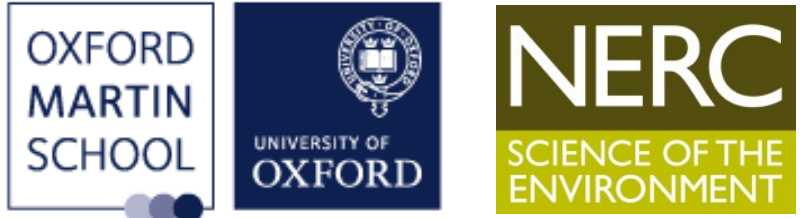


\section{References}

Abbott, J.G. \& Campbell, L.M. (2009) Environmental histories and emerging fisheries management of the Upper Zambezi river floodplains. Conservation and Society. 7 (2), 83-99.

Adger, W.N. (2006) Vulnerability. Global Environmental Change. [Online] 16 (3), 268-281. Available from: doi:10.1016/j.gloenvcha.2006.02.006.

Béné, C., Hersoug, B. \& Allison, E.H. (2010) Not by Rent Alone: Analysing the Pro-Poor Functions of Small-Scale Fisheries in Developing Countries. Development Policy Review. 28 (3), 325-358.

Berkes, F. (2009) Evolution of co-management: Role of knowledge generation, bridging organizations and social learning. Journal of Environmental Management. [Online] 90 (5), 1692-1702. Available from: doi:10.1016/j.jenvman.2008.12.001.

Bhatt, S., Weiss, D.J., Cameron, E., Bisanzio, D., et al. (2015a) The effect of malaria control on Plasmodium falciparum in Africa between 2000 and 2015. Nature. [Online] 526 (7572), 207-211. Available from: doi:10.1038/nature15535.

Bhatt, S., Weiss, D.J., Mappin, B., Dalrymple, U., et al. (2015b) Coverage and system efficiencies of insecticide-treated nets in Africa from 2000 to 2017. eLife. 4, e09672.

Bianchi, G. \& Skjoldal, H.R. (2008) The ecosystem approach to fisheries. FAO (ed.). Wallingford, UK ; Cambridge, MA : Rome, CABI ; Food and Agriculture Organization of the United Nations.

Bush, E.R., Short, R.E., Milner-Gulland, E.J., Lennox, K., et al. (2016) Mosquito Net Use in an Artisanal East African Fishery. Conservation Letters. [Online] 10 (4), 451-459. Available from: doi:10.1111/conl.12286.

Cassels, S., Curran, S.R. \& Kramer, R. (2005) Do Migrants Degrade Coastal Environments? Migration, Natural Resource Extraction and Poverty in North Sulawesi, Indonesia. Human Ecology. [Online] 33 (3), 329-363. Available from: doi:10.1007/s10745-0054142-9.

Caulfield, L.E., Richard, S.A. \& Black, R.E. (2004) Undernutrition as an underlying cause of malaria morbidity and mortality in children less than five years old. American Journal of Tropical Medicine and Hygiene. 71 (2), 55-63.

Darkey, D. \& Turatsinze, R. (2014) Artisanal Fishing in Beira, Central Mozambique. J Hum Ecol. 47 (3), 317-328. 
Diamond, N.K., Squillante, L. \& Hale, L.Z. (2003) Cross currents: navigating gender and population linkages for integrated coastal management. Marine Policy. [Online] 27 (4), 325-331. Available from: doi:10.1016/S0308-597X(03)00044-7.

Diekert, F.K. (2012) Growth Overfishing: The Race to Fish Extends to the Dimension of Size. Environmental and Resource Economics. [Online] 52 (4), 549-572. Available from: doi:10.1007/s10640-012-9542-x.

Dlamini, S.V., Liao, C.-W., Dlamini, Z.H., Siphepho, J.S., et al. (2017) Knowledge of human social and behavioral factors essential for the success of community malaria control intervention programs: The case of Lomahasha in Swaziland. Journal of Microbiology, Immunology and Infection. [Online] 50 (2), 245-253. Available from: doi:10.1016/j.jmii.2015.05.003.

Eisele, T.P., Thwing, J. \& Keating, J. (2011) Claims about the Misuse of Insecticide-Treated Mosquito Nets: Are These Evidence-Based? PLoS Medicine. [Online] 8 (4), e1001019. Available from: doi:10.1371/journal.pmed.1001019.

Erskine, M. \& Rockwood, J. (2013) AMP Toolkit 2.0 - A toolkit for mass distribution campaigns to increase coverage and use of long-lasting insecticide-treated nets. [Online]. Available from: https://coregroup.org/wp-content/uploads/mediabackup/Webinars/Malaria/AMPToolkit.pdf [Accessed: 30 August 2018].

FAO (2005) Increasing the contribution of small-scale fisheries to poverty alleviation and food security. FAO technical guidelines for responsible fisheries 10. Rome, Food and Agriculture Organization of the United Nations.

FAO (2015) Voluntary guidelines for securing sustainable small-scale fisheries in the context of food security and poverty eradication. Rome, Food and Agriculture Organization of the United Nations.

Fiorella, K.J., Milner, E.M., Salmen, C.R., Hickey, M.D., et al. (2017) Human health alters the sustainability of fishing practices in East Africa. Proceedings of the National Academy of Sciences. 201613260.

Garcia, S.M., Kolding, J., Rice, J., Rochet, M.-J., et al. (2012) Reconsidering the Consequences of Selective Fisheries. Science. [Online] 335 (6072), 1045-1047. Available from: doi:10.1126/science.1214594.

Global Partnership to Roll Back Malaria (2015) Actions and Investment for a Malaria-free world: 2016-2030. Geneva, World Health Organization.

Guyatt Helen L., Gotink Marinus H., Ochola Sam A. \& Snow Robert W. (2002) Free bednets to pregnant women through antenatal clinics in Kenya: a cheap, simple and 
equitable approach to delivery. Tropical Medicine \& International Health. [Online] 7 (5), 409-420. Available from: doi:10.1046/j.1365-3156.2002.00879.x.

Harper, S., Grubb, C., Stiles, M. \& Sumaila, U.R. (2017) Contributions by Women to Fisheries Economies: Insights from Five Maritime Countries. Coastal Management. [Online] 45 (2), 91-106. Available from: doi:10.1080/08920753.2017.1278143.

Harper, S., Zeller, D., Hauzer, M., Pauly, D., et al. (2013) Women and fisheries: Contribution to food security and local economies. Marine Policy. [Online] 39, 56-63. Available from: doi:10.1016/j.marpol.2012.10.018.

Hawley, W.A., Phillips-Howard, P.A., ter Kuile, F.O., Terlouw, D.J., et al. (2003) Communitywide effects of permethrin-treated bed nets on child mortality and malaria morbidity in western Kenya. The American journal of tropical medicine and hygiene. 68 (4_suppl), 121-127.

Hill, I.R. (1989) Aquatic organisms and pyrethroids. Pesticide Science. [Online] 27 (4), 429457. Available from: doi:10.1002/ps.2780270408.

Hlongwana, K.W., Mavundza, E.J., Mohapi, E.P., Kruger, P., et al. (2013) Vector-control personnel's knowledge, perceptions and practices towards insecticides used for indoor residual spraying in Limpopo Province, South Africa. Parasites \& Vectors. [Online] 6, 118. Available from: doi:10.1186/1756-3305-6-118.

Honjo, K. \& Satake, A. (2014) N-player mosquito net game: Individual and social rationality in the misuse of insecticide-treated nets. Journal of Theoretical Biology. [Online] 342, 39-46. Available from: doi:10.1016/j.jtbi.2013.11.001.

Howard, S.C., Omumbo, J., Nevill, C., Some, E.S., et al. (2000) Evidence for a mass community effect of insecticide-treated bednets on the incidence of malaria on the Kenyan coast. Transactions of the Royal Society of Tropical Medicine and Hygiene. 94 (4), 357360.

Jiddawi, N.S. \& Öhman, M.C. (2002) Marine Fisheries in Tanzania. AMBIO: A Journal of the Human Environment. [Online] 31 (7), 518. Available from: doi:10.1639/00447447(2002)031[0518:MFIT]2.0.CO;2.

Killeen, G.F., Kiware, S.S., Okumu, F.O., Sinka, M.E., et al. (2017a) Going beyond personal protection against mosquito bites to eliminate malaria transmission: population suppression of malaria vectors that exploit both human and animal blood. BMJ Global Health. [Online] 2 (2), e000198. Available from: doi:10.1136/bmjgh-2016000198.

Killeen, G.F. \& Smith, T.A. (2007) Exploring the contributions of bed nets, cattle, insecticides and excitorepellency to malaria control: a deterministic model of mosquito host- 
seeking behaviour and mortality. Transactions of the Royal Society of Tropical Medicine and Hygiene. [Online] 101 (9), 867-880. Available from:

doi:10.1016/j.trstmh.2007.04.022.

Killeen, G.F., Tatarsky, A., Diabate, A., Chaccour, C.J., et al. (2017b) Developing an expanded vector control toolbox for malaria elimination. BMJ Global Health. [Online] 2 (2), e000211. Available from: doi:10.1136/bmjgh-2016-000211.

Knols, B.G.J., Farenhorst, M., Andriessen, R., Snetselaar, J., et al. (2016) Eave tubes for malaria control in Africa: an introduction. Malaria Journal. [Online] 15. Available from: doi:10.1186/s12936-016-1452-x.

Koenker, H., Ricotta, E. \& Olapeju, B. (2018) Insecticide-Treated Nets (ITN) Access and Use Report.

Kolding, J. \& Zwieten, P. van (2014) Sustainable fishing of inland waters. Journal of Limnology. [Online] 73 (s1). Available from: http://www.jlimnol.it/index.php/jlimnol/article/view/jlimnol.2014.818 [Accessed: 18 May 2016].

Kolding, J., van Zwieten, P.A. \& Mosepele, K. (2015) Where there is water there is fish-Smallscale inland fisheries in Africa: dynamics and importance. In: A History of Water Series III, Volume 3: Water and Food. 3. London, I.B. Tauris. p.

Larsen, D.A., Welsh, R., Mulenga, A. \& Reid, R. (2018) Widespread mosquito net fishing in the Barotse floodplain: Evidence from qualitative interviews Ryan E. Wiegand (ed.). PLOS ONE. [Online] 13 (5), e0195808. Available from: doi:10.1371/journal.pone.0195808.

Mangi, S.C. \& Roberts, C.M. (2006) Quantifying the environmental impacts of artisanal fishing gear on Kenya's coral reef ecosystems. Marine Pollution Bulletin. [Online] 52 (12), 1646-1660. Available from: doi:10.1016/j.marpolbul.2006.06.006.

McLean, K.A., Byanaku, A., Kubikonse, A., Tshowe, V., et al. (2014) Fishing with bed nets on Lake Tanganyika: a randomized survey. Malar J. 13 (395), 10-1186.

Minakawa, N., Dida, G.O., Sonye, G.O., Futami, K., et al. (2008) Unforeseen misuses of bed nets in fishing villages along Lake Victoria. Malaria Journal. [Online] 7 (1), 165. Available from: doi:10.1186/1475-2875-7-165.

National Pesticide Information Centre (2000) Piperonyl Butoxide Technical Fact Sheet. [Online]. Available from: http://npic.orst.edu/factsheets/archive/pbotech.pdf [Accessed: 13 April 2018].

N'Guessan, R., Odjo, A., Ngufor, C., Malone, D., et al. (2016) A Chlorfenapyr Mixture Net Interceptor ${ }^{\circledR}$ G2 Shows High Efficacy and Wash Durability against Resistant 
Mosquitoes in West Africa John Vontas (ed.). PLOS ONE. [Online] 11 (11), e0165925. Available from: doi:10.1371/journal.pone.0165925.

Ngufor, C., N'guessan, R., Fagbohoun, J., Todjinou, D., et al. (2016) Efficacy of the Olyset Duo net against insecticide-resistant mosquito vectors of malaria. Science trans/ational medicine. 8 (356), 356ra121-356ra121.

Norris, L.C., Main, B.J., Lee, Y., Collier, T.C., et al. (2015) Adaptive introgression in an African malaria mosquito coincident with the increased usage of insecticide-treated bed nets. Proceedings of the National Academy of Sciences. [Online] 112 (3), 815-820. Available from: doi:10.1073/pnas.1418892112.

Picard, D. (2015) Making ecotourism sustainable: refocusing on economic viability. Lessons learnt from the "Regional strategic action plan for coastal ecotourism development in the South Western Indian Ocean". Journal of Sustainable Tourism. [Online] 23 (6), 819-837. Available from: doi:10.1080/09669582.2015.1019512.

Pomeroy, R., Parks, J., Pollnac, R., Campson, T., et al. (2007) Fish wars: Conflict and collaboration in fisheries management in Southeast Asia. Marine Policy. [Online] 31 (6), 645-656. Available from: doi:10.1016/j.marpol.2007.03.012.

Porter, M. \& Mbezi, R.G. (2010) From Hand to Mouth: Fishery Projects, Women, Men and Household Poverty. Canadian Journal of Development Studies. [Online] 31 (3), 21. Available from: doi:10.1080/02255189.2010.3673726.

Protopopoff, N., Mosha, J.F., Lukole, E., Charlwood, J.D., et al. (2018) Effectiveness of a longlasting piperonyl butoxide-treated insecticidal net and indoor residual spray interventions, separately and together, against malaria transmitted by pyrethroidresistant mosquitoes: a cluster, randomised controlled, two-by-two factorial design trial. The Lancet. [Online] 391 (10130), 1577-1588. Available from: doi:10.1016/S0140-6736(18)30427-6.

Pulford, J., Hetzel, M.W., Bryant, M., Siba, P.M., et al. (2011) Reported reasons for not using a mosquito net when one is available: a review of the published literature. Malar J. [Online] 10 (10). Available from: http://www.biomedcentral.com/content/pdf/14752875-10-83.pdf [Accessed: 26 November 2014].

Ranis, G., Frances, S. \& Alejandro, R. (2000) Economic Growth and Human Development. World Development. 28 (2), 197-219.

Sadasivaiah, S., Tozan, Y. \& Breman, J.G. (2007) Dichlorodiphenyltrichloroethane (DDT) for Indoor Residual Spraying in Africa: How Can It Be Used for Malaria Control? [Online]. American Society of Tropical Medicine and Hygiene. Available from: https://www.ncbi.nlm.nih.gov/books/NBK1724/ [Accessed: 13 April 2018]. 
Shankar, A.H. (2000) Nutritional modulation of malaria morbidity and mortality. The Journal of infectious diseases. 182 (Supplement_1), S37-S53.

Short, R., Gurung, R., Rowcliffe, M., Hill, N., et al. (2018) The use of mosquito nets in fisheries: A global perspective. Plos one. 13 (1), e0191519.

Sissenwine, M.P. \& Shepherd, J.G. (1987) An Alternative Perspective on Recruitment Overfishing and Biological Reference Points. Canadian Journal of Fisheries and Aquatic Sciences. [Online] 44 (4), 913-918. Available from: doi:10.1139/f87-110.

Srivastava, S.K., Sarkar, U.K. \& Patiyal, R.S. (2002) Fishing methods in streams of the Kumaon Himalayan region of India. Asian Fisheries Science. 15 (4), 347-356.

Thilsted, S.H., James, D., Toppe, J., Subasinghe, R., et al. (2014) Maximizing the contribution of fish to human nutrition. In: ICN2 Second International Conference on Nutrition. 2014 FAO and World Health Organisation. p.

Thilsted, S.H., Subasinghe, R.P., Arthur, J.R., Bartley, D.M., et al. (2013) The potential of nutrient-rich small fish species in aquaculture to improve human nutrition and health. In: Proceedings of the Global Conference on Aquaculture 2010. Farming the waters for people and food. [Online]. 2013 FAO/NACA. pp. 57-73. Available from: http://www.cabdirect.org/abstracts/20133399224.html [Accessed: 11 April 2016].

de la Torre-Castro, M., Fröcklin, S., Börjesson, S., Okupnik, J., et al. (2017) Gender analysis for better coastal management - Increasing our understanding of social-ecological seascapes. Marine Policy. [Online] 83, 62-74. Available from: doi:10.1016/j.marpol.2017.05.015.

van der Elst (2003) Local solutions to challenges of West Indian Ocean fisheries development. NAGA, WorldFish Center Quarterly. 26 (3), 14-17.

WHO (2014a) WHO recommendations for achieving universal coverage with long-lasting insecticidal nets in malaria control.

WHO (2014b) WHO recommended long-lasting insecticidal nets. [Online]. 2014. Available from: http://www.who.int/whopes/Long_lasting_insecticidal_nets_06_Feb_2014.pdf [Accessed: 24 August 2017].

WHO (2015) World Malaria Report 2015. World Health Organization, Geneva, Switzerland. pp157.

WHO (2017) World Malaria Report 2017. World Health Organization, Geneva, Switzerland. pp196. 
WHO Global Malaria Programme (2014) WHO recommendations on the sound management of old long-lasting insecticidal nets. [Online]. 2014. Available from:

http://www.who.int/malaria/publications/atoz/who-recommendation-managing-oldllins-mar2014.pdf [Accessed: 24 August 2017].

Williams, M.J., Williams, S.B. \& Choo, P.S. (2002) From women in fisheries to gender and fisheries. WOMEN IN FISHERIES: POINTERS FOR DEVELOPMENT. 13.

World Health Organization, World Health Organization \& Global Malaria Programme (2015) Global technical strategy for malaria, 2016-2030. 